\title{
The Yuli Belt in Taiwan: Part of the suture zone separating Eurasian and Philippine Sea plates
}

\author{
Yiqiong Zhang $^{1, *}$, Chin-Ho Tsai ${ }^{2}$, Nikolaus Froitzheim ${ }^{3}$, and Kamil Ustaszewski ${ }^{1}$ \\ ${ }^{1}$ Institute of Geosciences, Friedrich-Schiller-Universität Jena, Jena, Germany \\ ${ }^{2}$ Department of Natural Resources \& Environmental Studies, National Dong Hwa University, Hualien County, Taiwan \\ ${ }^{3}$ Institute of Geosciences, Rheinische Friedrich-Wilhelms-Universität Bonn, Bonn, Germany
}

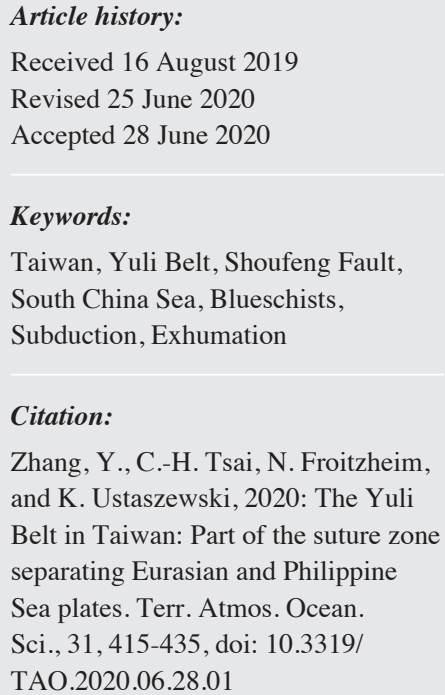

\begin{abstract}
The Yuli Belt exposed in the retro-wedge of the eastern part of the Taiwan orogen hosts slivers of a heterogeneous unit of blueschist-facies rocks. However, the question pertaining to its palaeogeographic provenance is still debated despite new geochronological data. This is largely because the structural geometries and kinematics of the Yuli Belt's tectonic contacts with its adjacent units are improperly understood. This paper presents new structural data from field work along several river transects in the Yuli Belt, which we combine with published data into a new tectonic model. Fieldwork and microstructural analyses indicate three deformation phases in the Yuli Belt. Based on cross sections and a review of available P-T-t data, we suspect that blueschist-facies units could have been emplaced on top of greenschist-facies metasedimentary units along a thrust during a first deformation phase D1. This assembly was later thrust over the Eurasian-derived Tailuko Belt along the Shoufeng Fault during D2, as suggested by W-plunging stretching lineations on fault-parallel foliation planes. D3 produced E-vergent folds with W- to NW-dipping axial planes, refolding earlier foliations as well as the D1 nappe contact. We suspect that this E-vergent folding could be related to top-E backthrusting observed along the Shoufeng Fault, involving its reorientation from an initially E-dipping to a presently W-dipping contact. The blueschist-facies metamorphic unit of the Yuli Belt likely represents a mid-Miocene fragment of oceanic crust and mantle issued in the South China Sea. It could hence be considered as part of the suture between the Eurasian and the Philippine Sea plates.
\end{abstract}

\section{INTRODUCTION}

Sutures or suture zones are variably sized allochthonous tectonic units occurring in every collisional orogen, separating tectonic units of contrasting palaeogeographic origin (Gansser 1964, 1980; Dewey 1987; Grasemann and Huet 2016). They typically contain ophiolitic fragments that represent relics of formerly larger amounts of oceanic crust and mantle lithosphere initially separating the continental units before subduction (Moores 1970; Moores and Vine 1971; Gansser 1980; Condie 2016). Put more simply, sutures are fossil collisional plate boundaries. Quite often, sutures form brittle or mylonitic shear zones that accommodated large amounts of contractional strain, providing

\footnotetext{
* Corresponding author

E-mail:yiqiong.zhang@uni-jena.de
}

testimony of plate convergence. Sutures regularly represent strongly tectonised zones with large lithological and metamorphic heterogeneity of mappable units, which are furthermore often spatially disrupted. Among the many heterogeneous lithologies encountered in suture zones, high-pressure metamorphosed rocks always receive particular attention, because they provide undisputable proof for subduction processes preceding collision (e.g., Stern 2005). This is also the case for the famous Yuli Belt of Taiwan, a tectonic unit on the eastern side of Taiwan's Central Range (Fig. 1). Its occurrences of blueschist-facies rocks have been the focus of continued petrological and geochronological investigations since the pioneering work of Yen (1959). The Yuli Belt contains lithologically heterogeneous blueschist-facies rocks in what is referred to as tectonic or exotic blocks (Table 1), 
which, according to numerous authors (e.g., Jahn and Liou 1977; Liou 1981; Yui et al. 2012; Tsai et al. 2013), are surrounded by an intensely deformed metasedimentary unit of lower metamorphic grade (Table 1 and Fig. 2). Internally, some of the high-pressure blocks are considered tectonic mélanges themselves, exhibiting four petrographically different types of glaucophane-bearing rocks (Tsai et al. 2013) with intervening metasediments such as garnet-bearing blackschists (Beyssac et al. 2008) or garnet paragonite mica schists (Keyser et al. 2016). Recent geochronological work on the blueschists has yielded a Lu-Hf age of $5.1 \pm 1.7 \mathrm{Ma}$ (Sandmann et al. 2015; see Table 2 for an overview of hitherto obtained geochronological data from the Yuli Belt) rendering it one of the youngest blueschists belts worldwide (Ota and Kaneko 2010).

The metasedimentary unit of the Yuli Belt (i.e., all units other than the aforementioned blueschist-bearing tectonic blocks) has been differentiated into four units (Wang et al. 1992; Yi et al. 2012), namely the Hutoushan Schists, Senjung Schists, Hungyeh Schists, and Albite spotted Schists. In the case of the first three units, lack of metamorphic index minerals and lithological similarities (mostly metapelitic to metapsammitic schists with variable amounts of carbonaceous matter) make it challenging to map differences between these lower amphibolite- to greenschist-facies units in terms of their structural position within the Yuli Belt. The sole more diagnostic lithology within the metasedimentary unit are the albite-bearing spotted schists (e.g., Yang and Wang 1985; see Table 1 for further references; Fig. 2).

The kinematics of the Shoufeng Fault, the tectonic contact between the Yuli Belt and the westerly adjacent Tailuko unit (Yen 1963), are little investigated. Lin et al. (1984) described the Shoufeng Fault as an NNE-striking and 70 $80^{\circ} \mathrm{W}$-dipping and topographically discernible feature, but no outcrop-scale faults were found. Recent geological maps (e.g., Lin and Chen 2016) depict the Shoufeng Fault essentially unchanged since Ho (1986). Chen et al. (2017) revised the fault trace (Fig. 2). However, the tectonic relationship between blueschist-facies units and the metasedimentary unit is poorly constrained.

In this study, we reinvestigated the tectonic evolution of the Yuli Belt with particular emphasis on the structural relationships between its blueschist-facies rocks and the metasedimentary unit. We build on recent geochronological results (e.g., Chen et al. 2017), incorporating own structural data from several river transects. Three new cross-sections across the Yuli Belt were constructed, suggesting that the blueschist-facies unit tectonically overlies the metasedimentary unit along a thrust that was later tightly folded together with the adjacent units of the Yuli Belt. Finally, relying on a simple plate tectonic reconstruction, we suggest that the Yuli Belt blueschist-facies unit could have originated from the oceanic crust of the South China Sea before its subduction below the Philippine Sea Plate. Since this unit at present occupies a structural position between series derived from Eurasia and those from the Philippine Sea Plate, it represents part of the suture zone.

\section{PLATE TECTONIC SETTING AND REGIONAL GEOLOGY}

Several geodynamic events have shaped Taiwan throughout the Cenozoic (Fig. 3). The collision between the Eurasian passive continental margin and the Luzon island arc of the overriding Philippine Sea plate formed (and keeps forming) the spectacular topography of the Taiwan mountain belt since about 4 to $6 \mathrm{Ma}$ (Chang and Chi 1983; Suppe 1984; Teng 1990; Yu and Chou 2001; Lee et al. 2015; Fig. 1). The Philippine Sea plate moves towards NW at $60-90 \mathrm{~mm} \mathrm{yr}^{-1}$ (e.g., Seno 1977; Yu et al. 1997). In the south of Taiwan, Eurasian lithosphere subducts southeastward underneath the Philippine Sea plate. This geometry is inherited from the intra-oceanic subduction of South China Sea lithosphere underneath the Philippine Sea plate, which commenced after the end of spreading in the South China Sea at around the early Middle Miocene (c. 16 Ma; Taylor and Hayes 1983; Sibuet et al. 2002; Fig. 3). While intra-oceanic subduction still prevails south of Taiwan along the Manila trench (e.g., Angelier 1986; Reed et al. 1992; Malavieille et al. 2002), advanced collisional shortening on the island of Taiwan has already led to the exposure of blueschist-facies rocks in the Yuli Belt of the eastern Central Range (Huang et al. 2006; Yui et al. 2012; Fig. 2).

Spreading of the South China Sea commenced at approximately $34 \mathrm{Ma}$ (e.g., IODP Site U1435; Li et al. 2017) and stopped at c. $15.5 \mathrm{Ma}$ (based on magnetic anomalies; Taylor and Hayes 1983; Briais et al. 1993; Sibuet et al. 2002). Subsequently, the oceanic lithosphere of the South China Sea started subducting under the Philippine Sea Plate as early as c. 15 - 16 Ma (Huang et al. 2006). This was inferred from ages of island arc rocks from Taiwan's Coastal Range, which forms a northward extension of the Luzon arc. Magmatism in the Coastal Range commenced in Early to Middle Miocene, as recorded by $\mathrm{Rb}-\mathrm{Sr}, \mathrm{K}-\mathrm{Ar}$, $\mathrm{Ar}-\mathrm{Ar}$, and fission track geochronological studies (e.g., Chi et al. 1981; Richard et al. 1986; Juang and Chen 1990; Lo et al. 1994; Lo and Yui 1996; Fig. 3). This is supported by more recently obtained U-Pb zircon ages of c. 14.2 Ma in the Chimei complex (Shao et al. 2015). Geochronological studies on the East Taiwan Ophiolite (ETO) contained Lichi Mélange yielded U-Pb magmatic zircon ages of 14 - $17 \mathrm{Ma}$ (Shao et al. 2015; Hsieh et al. 2017; Huang et al. 2018; Lin et al. 2019). Similar ages of $15.6 \pm 0.3$ and $16.0 \mathrm{Ma}$ were also obtained by U-Pb dating of zircons from blueschists in the Yuli Belt (Chen et al. 2017), suggesting very similar early Middle Miocene protolith ages as for the mafic rocks in the ETO (Table 1 and Fig. 3).

The five major morphotectonic units making up the 


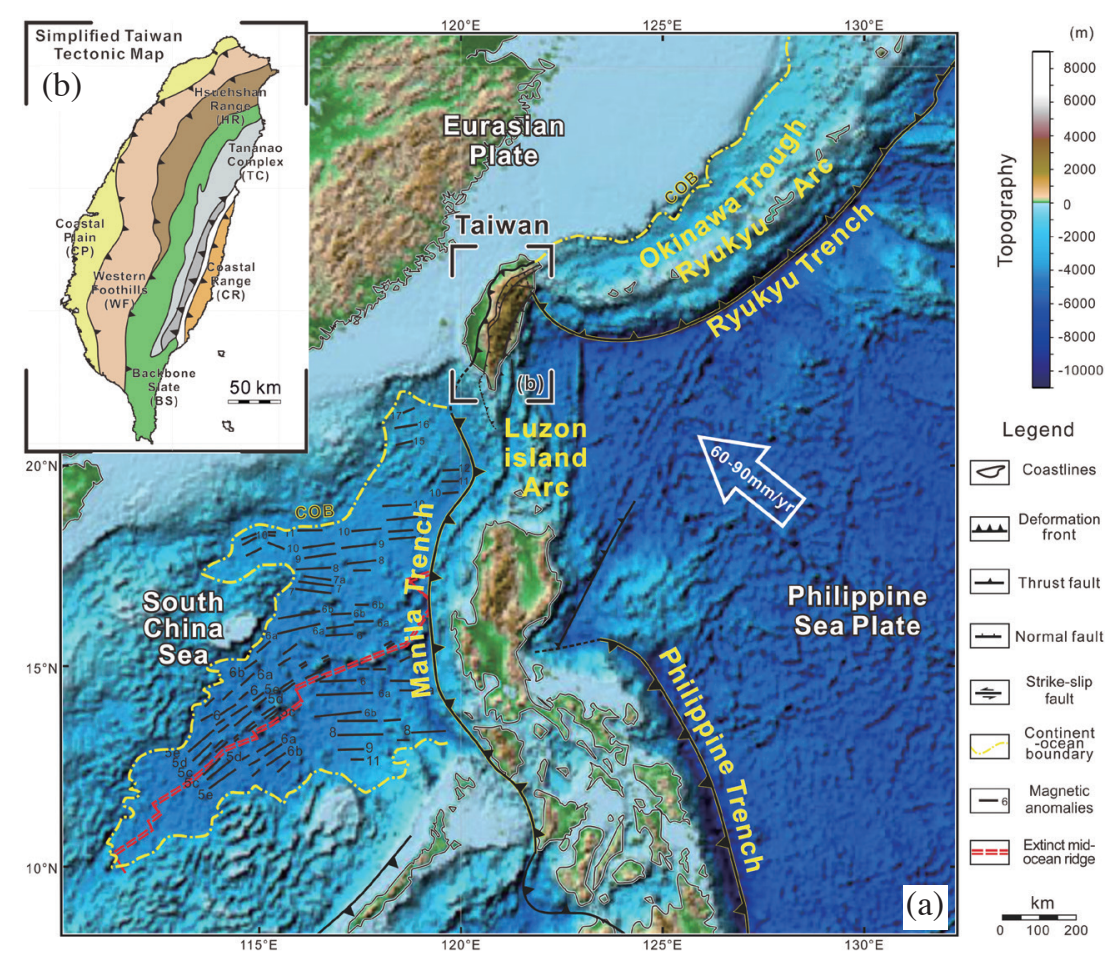

Fig. 1. Plate tectonic map of Taiwan and its greater surroundings showing main tectonic units. The Philippine Sea Plate moves towards the Eurasian Plate at a rate of c. $60-90 \mathrm{~mm} \mathrm{yr}^{-1}$ and subducts underneath it along the Ryukyu trench. The South China Sea (part of Eurasian Plate) subducts beneath the Philippine Sea Plate along the Manila Trench. The extinct South China Sea spreading ridge and magnetic lineations after Yeh et al. (2010); global topography model ETOPO1 (Amante and Eakins 2009); continent-ocean boundary (COB) from Sibuet et al. (2016).

Table 1. Comparison of the Yuli Belt and the Lichi mélange.

\begin{tabular}{|c|c|c|c|c|c|}
\hline & Rock type & Protolith & Age & \multicolumn{2}{|c|}{ Inferred Origin } \\
\hline \multicolumn{6}{|c|}{ Yuli Belt } \\
\hline \multirow{2}{*}{ Matrix } & $\begin{array}{l}\text { albite-garnet prophyroblastic schists } \\
\text { ("spotted schists") }{ }^{1,2,3,4}\end{array}$ & terrigenous clay? & \multirow{2}{*}{$\begin{array}{l}\text { protolith ages } \\
\text { unknown }\end{array}$} & & \\
\hline & paragonite-white mica metapelitic schists ${ }^{5}$ & pelagic clay? & & & \\
\hline \multirow{8}{*}{$\begin{array}{c}\text { Tectonic } \\
\text { blocks }\end{array}$} & serpentinite ${ }^{6}$ & peridotite & \multirow{7}{*}{$\begin{array}{l}\text { protolith ages } \\
\text { unknown }\end{array}$} & \multirow{8}{*}{$\begin{array}{l}\text { Middle-Late Miocene } \\
\text { accretionary prism }{ }^{15,16}\end{array}$} & \multirow{8}{*}{ PSP fore-arc ${ }^{12,17}$} \\
\hline & rodingite $^{6}$ & metasomatized mafics & & & \\
\hline & meta-gabbro $^{7}$ & gabbro & & & \\
\hline & meta-plagiogranite $^{8}$ & plagiogranite & & & \\
\hline & epidote amphibolite $7,8,9,10$ & gabbro, basalt & & & \\
\hline & greenschist $^{7,8}$ & basalt & & & \\
\hline & garnet-epidote amphibolite ${ }^{6}$ & tuff, basalt? & & & \\
\hline & glaucophane schists $9,10,11,12,13,14$ & $\begin{array}{l}\text { tuff, basaltic andesite, } \\
\text { Mn-rich pelagic clay? }\end{array}$ & $\sim 15 \mathrm{Ma}^{16,18}$ & & \\
\hline \multicolumn{6}{|c|}{ Lichi Mélange } \\
\hline Matrix & \multicolumn{2}{|c|}{ Sheared mudstone without stratification } & $\begin{array}{r}3.5-3.7 \mathrm{Ma}^{\mathrm{a}, \mathrm{b}, \mathrm{c}} ; \\
3.4-4.3 \mathrm{Ma}^{\mathrm{i}}\end{array}$ & & \\
\hline \multirow[t]{2}{*}{$\begin{array}{c}\text { Tectonic } \\
\text { blocks }\end{array}$} & \multicolumn{2}{|c|}{$\begin{array}{l}\text { ophiolitic rocks (East Taiwan Ophiolite/ETO), incl. Ultramafics } \\
\text { (serpentinized harzburgite, serpentinite breccia) }{ }^{\mathrm{d}, \mathrm{e}} \text {, gabbro }{ }^{\mathrm{f}} \text {, dikes of } \\
\text { dolerite and plagiogranite }{ }^{\mathrm{g}} \text {, pillow basalts }{ }^{\mathrm{f}}\end{array}$} & $\begin{array}{c}\text { Mid-Late } \\
\text { Miocene }^{\mathrm{f}, \mathrm{h}, \mathrm{j}}\end{array}$ & \multicolumn{2}{|c|}{$\operatorname{SCS}^{\mathrm{d}, \mathrm{e}, \mathrm{f}}$} \\
\hline & \multicolumn{2}{|l|}{ sedimentary rocks } & Mio-Pliocene ${ }^{\mathrm{a}, \mathrm{b}}$ & \multicolumn{2}{|c|}{$\mathrm{SCS}^{\mathrm{d}, \mathrm{e}}$} \\
\hline
\end{tabular}

Note: References for Yuli Belt: 1: Yang and Lin 1982; 2: Lin et al. 1984; 3: Yang and Wang 1985; 4: Chiang 2003; 5: Shen and Yang 1996; 6: Lan and Liou 1981; 7: Liou 1981; 8: Lan and Liou 1984; 9: Yen 1966; 10: Liou et al. 1975; 11: Jahn and Liou 1977; 12: Jahn et al. 1981; 13: Lo and Yui 1996; 14: Juang and Bellon 1986; 15: Liou and Ernst 1984; 16: Chen et al. 2017; 17: Beyssac et al. 2008; 18: Lo et al. 2020. References for Lichi Mélange: $a$ : Chi et al. 1981; b: Chang and Chi 1983; c: Barrier and Muller 1984; d: Suppe and Liou 1979; e: Suppe 1984; f: Lin et al. 2019; g: Shen et al. 1984; : Suppe et al. 1977; i: Chen et al. 2015; j: Lo et al. 2020. 


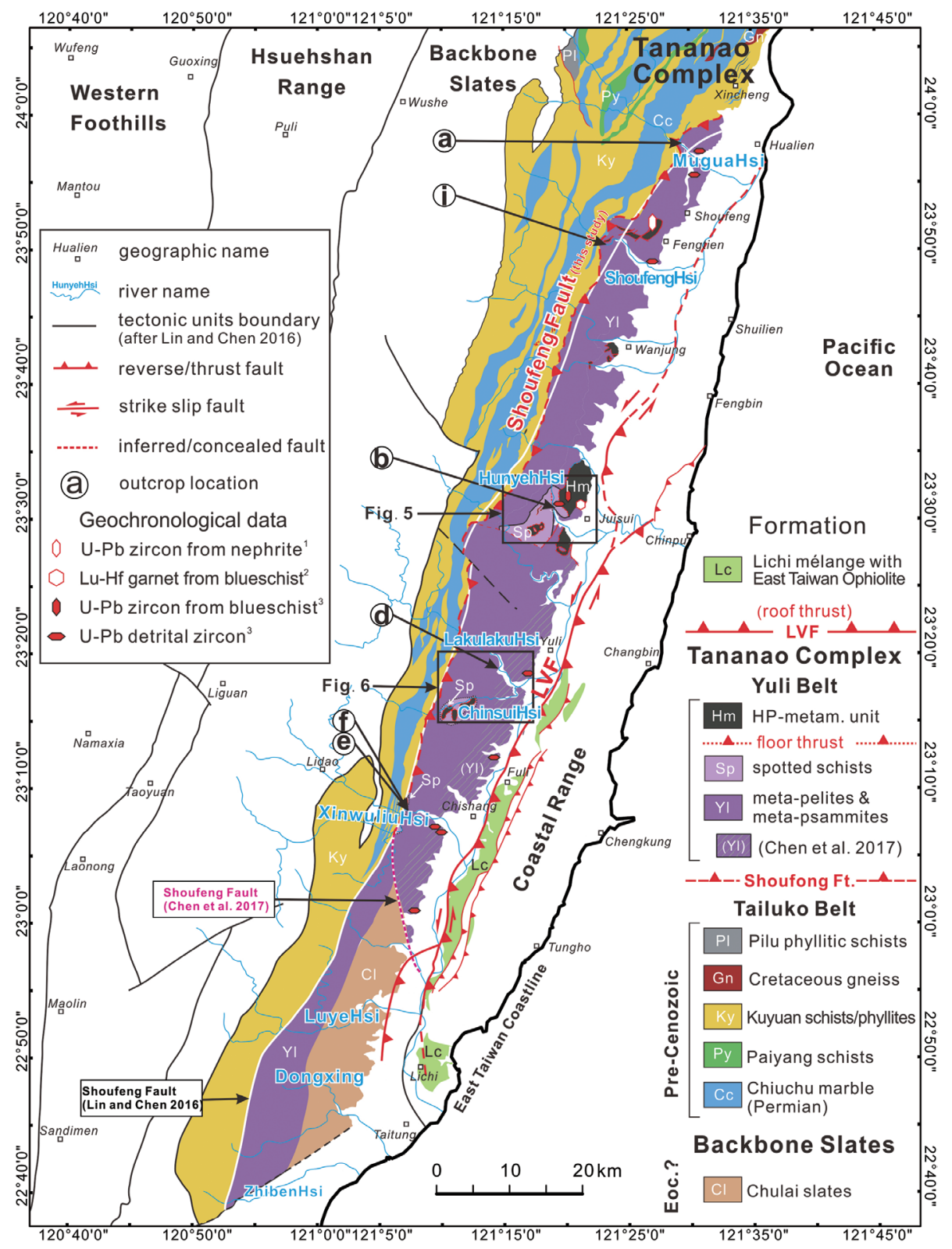

Fig. 2. Geological map of the metamorphic units exposed in the eastern part of Taiwan's Central Range (modified after Lin and Chen 2016). The Lichi Mélange is after Huang et al. (2006). The Yuli Belt hosts exotic blueschist-facies meta-igneous and ultramafic rocks (Hm) that we consider tectonically emplaced on top of an amphibolite- to greenschist-facies, polyphasely deformed metasedimentary unit (Yl). The diagonally dashed area of the Yuli Belt is adopted from Chen et al. 2017. Occurrences of spotted schists (Sp) are based on Yi et al. (2012) and Lo (2018). Locations of outcrops in Fig. 7 and thin sections in Fig. 9 are marked by small letters. Longitudinal Valley Fault (LVF) is from Shyu et al. (2005). Geological units outside Tananao Complex and Chulai Formation are not differentiated. Sources for the geochronological data in superscripts: 1: $3.3 \pm 1.7$ Ma (Yui et al. 2014); 2: 5.1 +1.7 Ma (Sandmann et al. 2015); 3: 15.4 - 16.0 Ma for blueschist; 1900 - 1700, 1000 - 900, 850 - 700, 200 - 65, and 65 - 8 Ma for metasediments (Chen et al. 2017). 


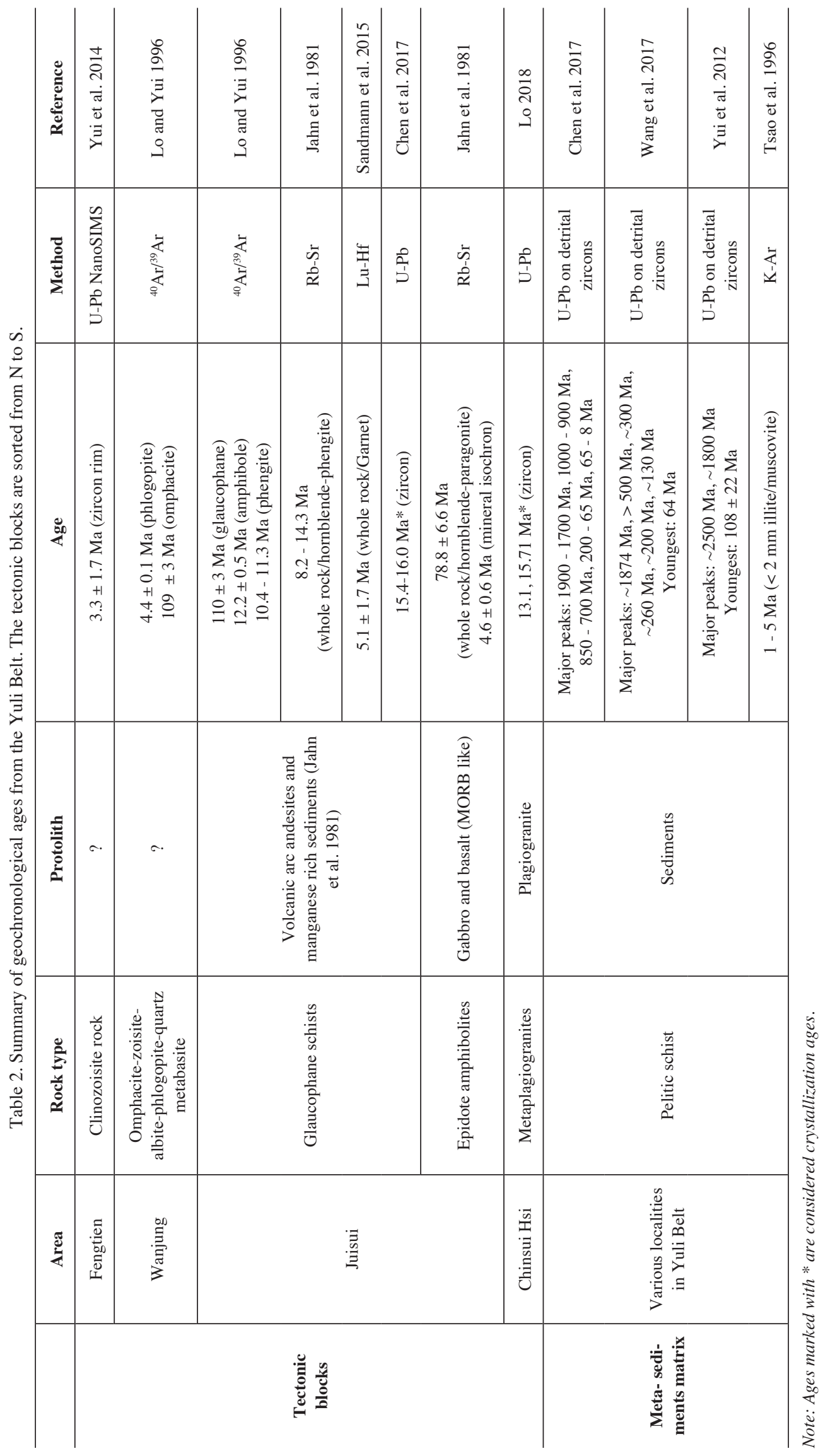




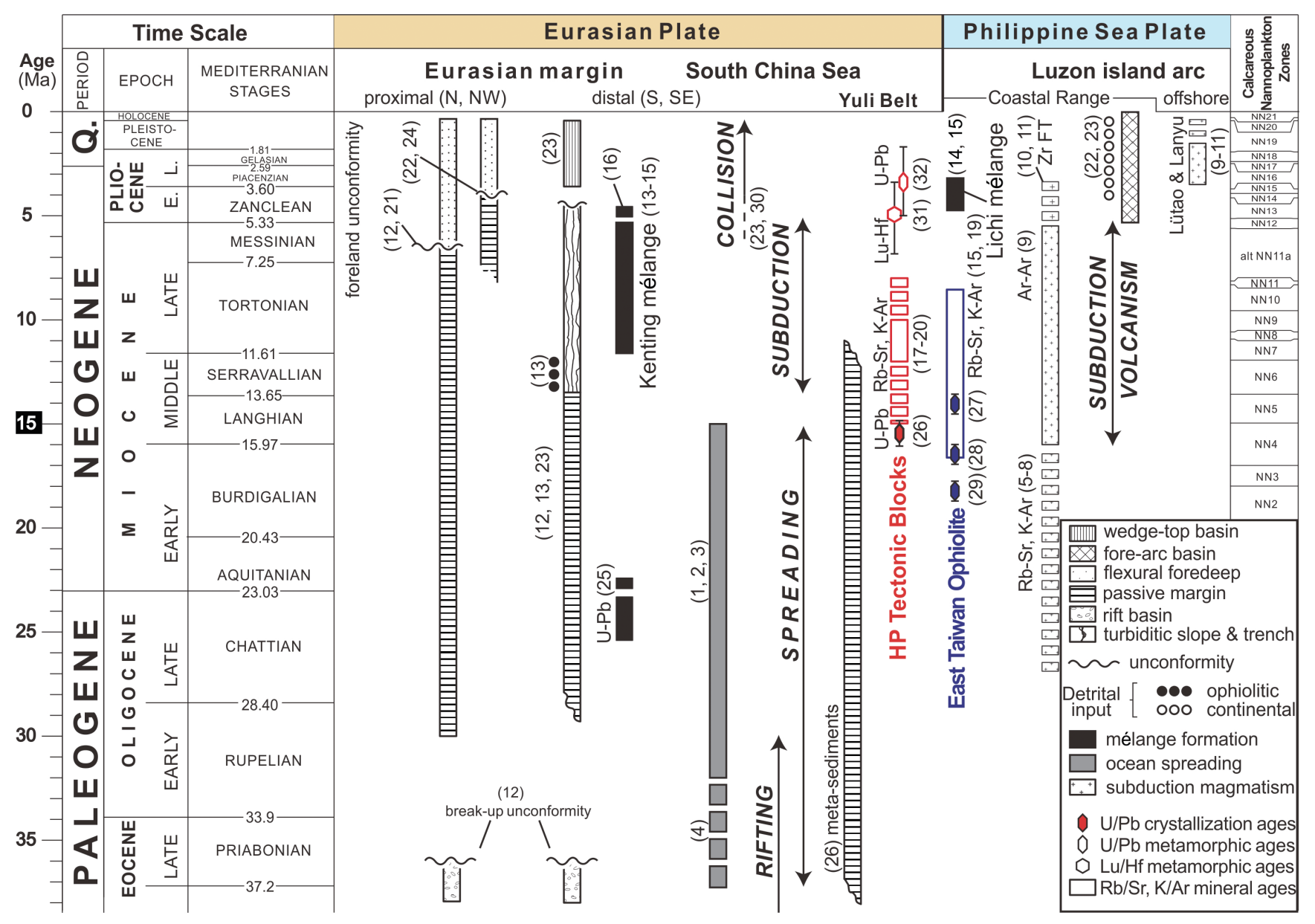

Fig. 3. Tectonostratigraphic chart reviewing timing of major geodynamic events around Taiwan. Recent geochronological ages are highlighted. Note discrepancies on the onset of continent-arc collision and uncertainties on the timing of pre-collisional metamorphism in the Yuli Belt. Sources: (1) Taylor and Hayes 1983; (2) Briais et al. 1993; (3) Sibuet et al. 2002; (4) Hsu et al. 2004; (5) Lan et al. 1996; (6) Richard et al. 1986; (7) Juang 1988; (8) Juang and Chen 1990; (9) Lo et al. 1994; (10) Chen et al. 1992; (11) Yang et al. 1995; (12) Lin and Watts 2002 and Lin et al. 2003; (13) Pelletier and Stephan 1986; (14) Page and Lan 1983; (15) Chang and Chi 1983; (16) Huang et al. 1983; (17) Jahn and Liou 1977; (18) Jahn et al. 1981; (19) Juang and Bellon 1986; (20) Lo and Yui 1996; (21) Yu and Chou 2001; (22) Chi et al. 1981; (23) Huang et al. 2006; (24) Chen et al. 2001; (25) Tian et al. 2019; (26) Chen et al. 2017; (27) Hsieh et al. 2017; (28) Lin et al. 2019; (29) Huang et al. 2018; (30) Teng 1990; (31) Sandmann et al. 2015; (32) Yui et al. 2014. Geologic time scale after Gradstein et al. (2012). 
Taiwan mountain belt are illustrated as tectonostratigraphic columns in Fig. 4 (Ho 1986; Chen and Wang 1995). From west to east and separated by major faults, these are the Western Foothills, the Hsuehshan Range, the Backbone Slates, the Tananao Complex, and the Coastal Range. Tananao Complex and Coastal Range are separated by the Longitudinal Valley Fault (LVF, Figs. 2 and 4). Units west of the LVF are derived from the Eurasian Plate. The Western Foothills, the Hsuehshan Range, and the Backbone Slates comprise the imbricated, parautochthonous Cenozoic passive margin sequence of sandstones, conglomerates, argillites and slates structurally below the Tananao Complex (e.g., Yue et al. 2005; Beyssac et al. 2008). The deformation of those three imbricates involves the pro-wedge of Taiwan fold-and-thrust belt with the earliest fabrics of east-dipping bedding planes (S0) and slaty cleavage (S1) (e.g., Pelletier and Hu 1984; Fisher et al. 2007; Naylor and Sinclair 2007; Supplementary, Table S1). East of the LVF is the Coastal Range, consisting of Neogene calc-alkaline arc volcanics and associated volcanodetrital sediments, as well as the Huatung forearc basin deposits (e.g., Huang et al. 2018). A progressive increase in continental contamination of andesitic magmas correlates with progressively younger ages in Coastal Range volcanic rocks (e.g., Chi et al. 1981; Dorsey 1992; Shao et al. 2015). The transition from oceanic to incipient continental subduction likely induced the subduction of a slice of the forearc lithosphere (e.g., Malavieille et al. 2002; Wu et al. 2008; Sandmann et al. 2015). The forearc lithosphere of the Philippine Sea Plate is suspected to subduct beneath the Coastal Range at about $22^{\circ} \mathrm{N}$ and is probably absent north of $24^{\circ} \mathrm{N}$, shortly before the cessation of island-arc magmatism (Kao et al. 2000; Sibuet et al. 2002; Shyu et al. 2011).

The Tananao Complex crops out as a narrow belt west of the LVF and bears evidence of polymetamorphism and multiple deformations (e.g., Ernst and Jahn 1987). Traditional nomenclature subdivides the Tananao Complex into the western Tailuko Belt and the eastern Yuli Belt (Ho 1986; Chen and Wang 1995), separated by the Shoufeng Fault (Yen 1963; Figs. 2 and 4). The Tailuko Belt consists of Permian marbles, variegated Mesozoic metapelites, and greenschists (Liou 1981), intruded by the Late Cretaceous Kanagan granitic gneiss (Jahn et al. 1986; Figs. 2 and 4). The Yuli Belt is dominantly composed of greenschist facies, often highly carbonaceous quartz-mica schists with blocks of metabasites up to blueschist facies (Fig. 2). Three larger exposures of these blocks are the Wanjung, Juisui, and Chinsui Hsi areas (Yen 1963; Liou et al. 1975; Liou and Ernst 1984; Yui and Lo 1989; Tsai et al. 2013; Table 2 and Fig. 2). The Yuli Belt's eastern contact with the Eocene (?) Chulai Formation of the Backbone Slates is a sharp boundary in terms of lithology and metamorphic grade, previously interpreted as an unconformity (Stanley et al. 1981; Ho 1986). However, based on comparable ages on detrital zircons from the
Yuli Belt metasediments and the northern part of the Chulai Formation (Lin and Chen 2016) as young as Miocene, the Chulai Formation has been recently reinterpreted as part of the metasediments of the Yuli Belt (e.g., Chen et al. 2017, 2019; Conand et al. 2020).

\section{NEW MESO- TO MICROSCALE OBSERVATIONS IN THE YULI BELT}

\subsection{Mesoscale Structures in the Metasedimentary Unit}

We made new outcrop-scale structural observations in the metasedimentary unit along several rivers crossing the Yuli Belt (Fig. 2). Mutual overprinting relationships between the observed structural elements suggest that they were formed during three successive deformation phases, termed D1, D2, and D3 in the following (Figs. 5, 6, 7, and 8). The S1 foliation forms a compositional layering, discernible for instance in the often graphite-rich metapelites to metasandstones in the Mugua Hsi area, where it is found to be overprinted by a moderately NW- to Wdipping S2 foliation developing a spaced crenulation or pressure-solution cleavage (Figs. 7a and 8-1). Closer to the Shoufeng Fault, e.g. along the Shoufeng Hsi itself, S2 foliations usually form a more densely spaced and pervasive $\mathrm{W}$ to NW-dipping compositional layering (Fig. 8-2), carrying rare WSW-plunging stretching lineations (Fig. 8-2) that we tentatively interpret as being associated with shear displacement along the Shoufeng Fault itself during deformation phase D2 or D3 (Fig. 2).

We found S2 to be often folded during a later deformation phase D3 (Figs. 7b, c, d, and 8-2). On the outcrop scale, the intensity of this D3 deformation depends on the lithology. S3 foliations form an open axial plane to crenulation cleavage that is well-developed in the metapelitic layers, and absent in the metapsammites (Fig. 7b) owing to the competence contrast. In proximity to the Shoufeng Fault, axial planes dip clearly to the west (Fig. 8-2). On a regional scale, we interpret S3 to form gently to moderately W-dipping axial planes associated with kilometer-scale E-vergent folding of the entire Yuli Belt succession (Figs. 5 and 6), most likely in conjunction with a major phase of E-facing back-folding of eastern parts of the Taiwan orogen (Yeh 2004; Fisher et al. 2007), termed here D3.

Cross section A-B (Fig. 5) also portrays a late-stage brittle normal fault (Hunyeh Hsi Fault), which shows only minor offset and that is hence considered of no importance here. In general, however, late stage brittle faulting is well documented in the eastern Central Range (e.g., Crespi et al. 1996; Table S1).

\subsection{Shoufeng Fault}

Previous maps have depicted the Shoufeng Fault as a quasi-vertical planar discontinuity separating Tailuko and 


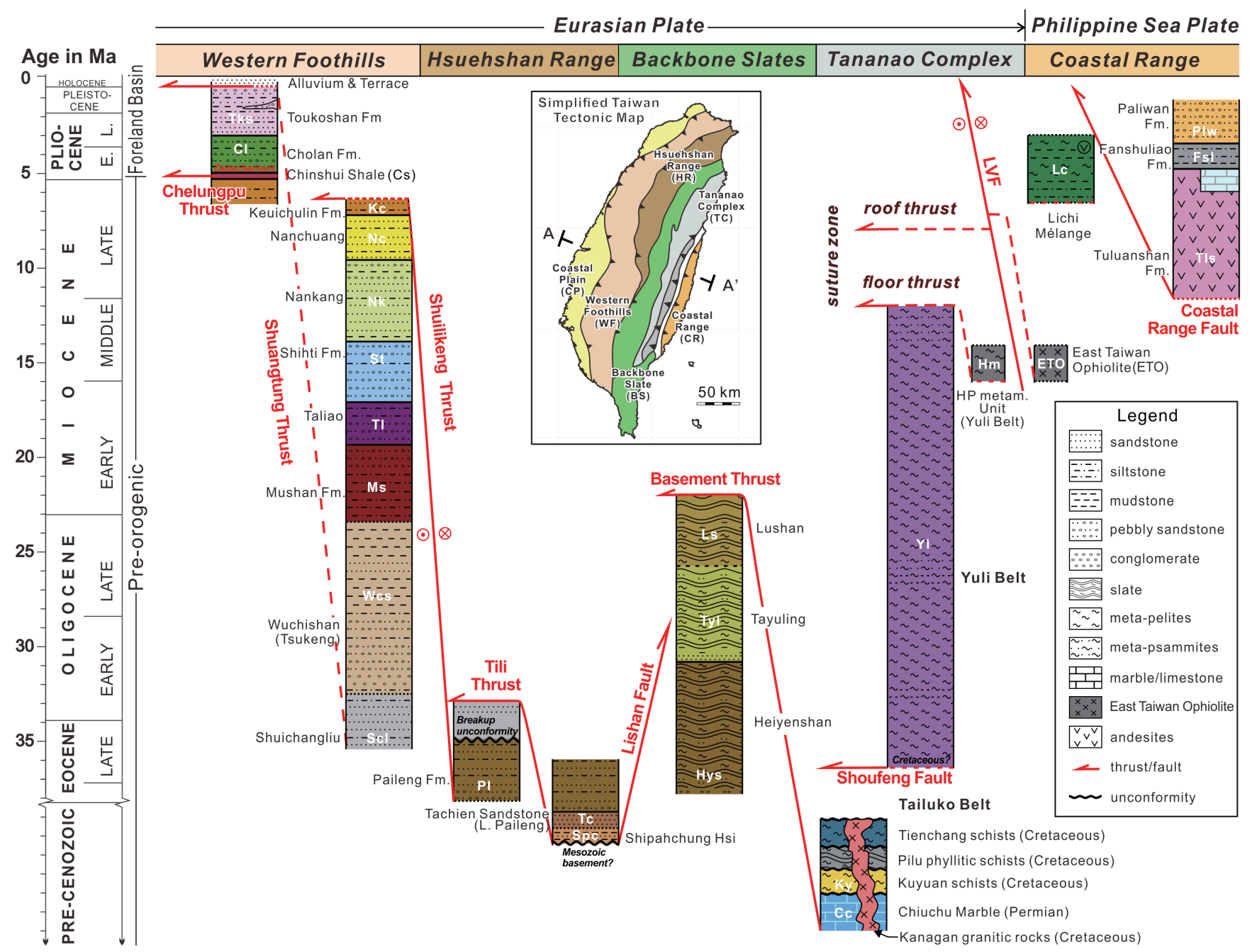

Fig. 4. Schematic tectonostratigraphic columns portraying the stratigraphic ranges of the major tectonic units and their mutual fault-bound relationships shown (based and modified after Yue et al. 2005; Brown et al. 2012; Chen et al. 2017; Huang et al. 2018, and references therein). We conceptually treat the blueschist-facies rocks of the Yuli Belt as occupying the position of part of the suture zone separating Eurasian and Philippine Sea plates, bound by a floor thrust and a roof thrust. The Longitudinal Valley Fault possibly overprinted the earlier roof thrust. 

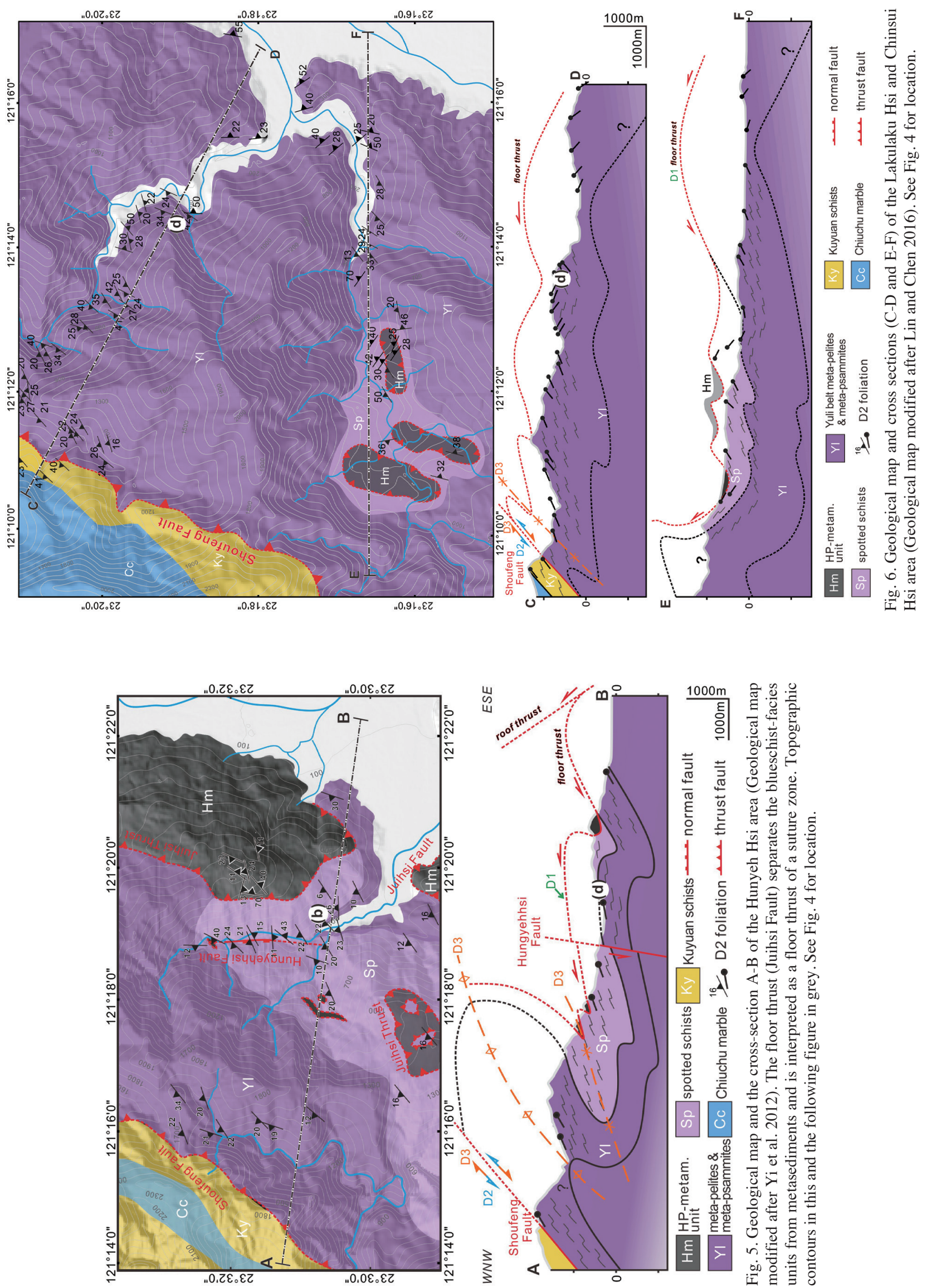

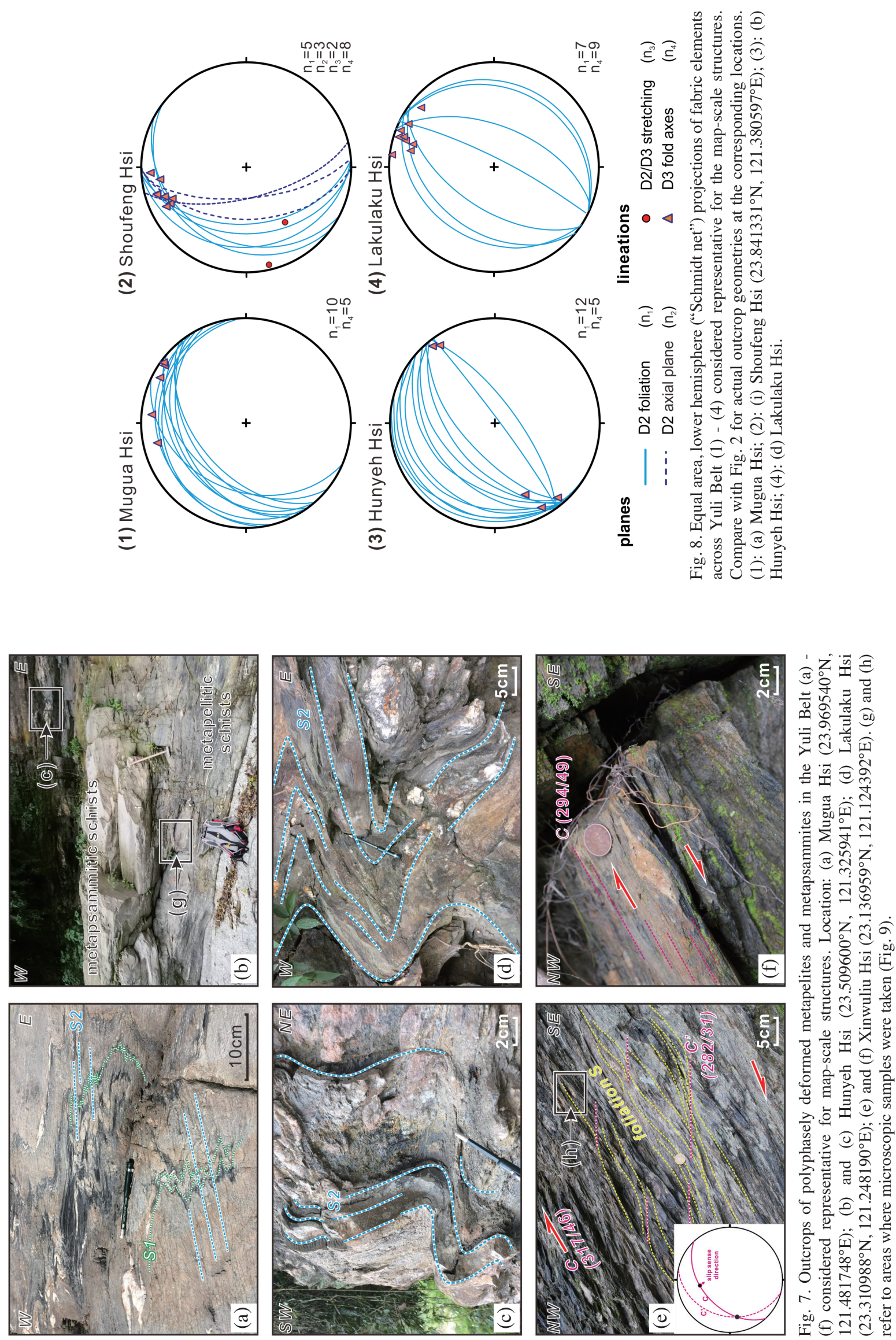
Yuli Belts. We have partly remapped the trace of the northern segment of the Shoufeng Fault to better agree with the actually observed gently NW- to W-dipping S2 foliations observed in several river transects (Figs. 2, 5, and 6). The southern part of the Shoufeng Fault still follows the interpretations of Lin and Chen (2016), but also depicts the alternative trace suggested by Chen et al. (2017; Fig. 2, thinly dashed red line). Dip direction and dip of S2 foliations are mostly $\mathrm{W}$ - to NW-dipping and remain constant across the contact. Also, the lithological and fabric transitions across this fault (e.g., Kuyuan schist of Tailuko Belt and Yuli Belt metasedimentary unit, along Hunyeh Hsi and Lakulaku Hsi, Figs. 2, 6, and 8) are gradual. Both Kuyuan schist and Yuli Belt metasedimentary unit appear very similar to undistinguishable in the field, as they are mainly composed of quartz-mica schists. We suspect that the juxtaposition of Yuli and Tailuko Belts across the Shoufeng Fault may have occurred during an early $\mathrm{W}$-directed transport direction (D2 phase). This interpretation is made on the notion that the Yuli Belt metasediments experienced elevated pressures of up to $1.5 \mathrm{GPa}$ (Conand et al. 2020), which have not been reported in the westerly adjacent Tailuko Belt. We suspect that the Shoufeng Fault became reoriented and reactivated with an opposite slip sense during a later phase of E-vergent backfolding (termed here D3 phase; Figs. 7e, f). Evidence for such top-SE shear was found in an outcrop of spotted schists from Xinwuliu Hsi, close to the Shoufeng Fault (Figs. 7e, f, 9h). There, S-C' fabrics with a C-foliation (dip direction and dip 317/46) and C' shear bands (dip direction and dip 282/31) have accommodated SE-directed shear (Figs. 7e, f, 9h). We interpret these top-SE senses of shear to also belong to D3 phase of backfolding, which overprints earlier (D2) top-W emplacement fabrics along the Shoufeng Fault.

\subsection{Microstructural Observations from the Spotted Schist Subunit}

The mineralogically most distinctive unit within the metasedimentary unit of the Yuli Belt is the albite spotted schists, separately mapped in Fig. 2, relying on Lin et al. (1984), Yi et al. (2012), and Lo (2018). The spots in these metapelites are formed by albite and - to a smaller amount - garnet and titanite porphyroblasts (Yang and Wang 1985; Fig. 9). The characteristic mineral assemblage of these schists is albite, garnet, muscovite, chlorite, titanite, \pm tourmaline, \pm calcite, and \pm rutile (Chiang 2003), as well as a variable amount of carbonaceous matter. Our observations suggest that the growth of albite porphyroblasts with graphitic inclusions predated the formation of the $\mathrm{S} 3$ foliation. This is evidenced in a sample from the Juisui/Hunyeh Hsi area (Fig. 9g), which shows that asymmetrically rotated albite with graphitic inclusions and chlorite in pressure shadows forms a porphyroclast with respect to the older S2 fo- liation. In the sample from Xinwuliu Hsi, albite and titanite form porphyroclasts that are pre-kinematic with respect to the younger foliation (Fig. 9h). This younger foliation forms pervasive C-planes with enrichment of carbonaceous material. S-C' type of shearing clearly transposes an older compositional layering $\mathrm{S}$ that can be identified in isolated microlithons. Chlorite is locally observed to form at the expense of biotite and grows in the main foliation, implying that this fabric formed at greenschist-facies conditions. In combination, these observations suggest that peak-metamorphic conditions in the spotted schists were attained before the D3 event that locally forms the penetrative fabrics observed. This would be in support of our hypothesis portrayed in cross sections (Figs. 5 and 6), according to which the nappe structure within the Yuli Belt was refolded during D3.

\section{DISCUSSION}

\subsection{Structural Position of the Yuli Belt High-Pressure Blocks with Respect to Adjacent Units}

By correlating outcrop-scale observations with cross sections, we interpreted the high-pressure metamorphosed blocks to form allochthonous nappe outliers (or erosional relics) of a formerly more contiguous thrust sheet, which emplaced subducted and exhumed portions of crust and mantle on top of the lower-grade metasedimentary unit (Figs. 5 and 6). In the following, we term this fault "Juihsi Thrust" after the locality with the largest exposures of blueschist-facies rocks (Fig. 5). Nappe emplacement must have occurred after peak-P-T conditions in the high-pressure unit have been reached. This interpretation is supported by contrasting P-Tconditions in the blueschist-facies and the metasedimentary units (Supplementary, Fig. S1). Peak pressures and temperatures obtained for the high-pressure unit (c. 1.0 to $1.7 \mathrm{GPa}$ and $500-550^{\circ} \mathrm{C}$, respectively; Beyssac et al. 2008; Tsai et al. 2013; Sandmann et al. 2015; Keyser et al. 2016; Baziotis et al. 2017; Lo 2018; Fig. S1) are higher than those of the metasedimentary unit (c. $0.3-0.9 \mathrm{GPa}$ and $500-546^{\circ} \mathrm{C}$, respectively; Chiang 2003; Beyssac et al. 2008; Fig. S1), although more recent work suggests substantially higher pressures, but lower temperatures for the metasediments (up to $1.5 \mathrm{GPa}$ and $330-400^{\circ} \mathrm{C}$; Conand et al. 2020). These contrasting P-T-conditions nourish our assumption of two tectonic units that require to be separated by a thrust. The juxtaposition of high-pressure blueschist unit and metasedimentary unit along this thrust occurred very likely during D1 or early D2; certainly before the refolding of all units during D3 and likely concomitant with late-stage retrogression at greenschist facies conditions below c. $3 \mathrm{kbar}$ and $370^{\circ} \mathrm{C}$ (Figs. S1, 10). This is in agreement with our cross sections with the west-dipping axial planes formed during D3 (Figs. 5, 6, and 8b). D3 refolding and back-thrusting, in combination with later erosion, was responsible for the separation of high-pressure rock occurrences in map view. The 
idea of the existence of such thrusts was first proposed by Yang and Wang (1985). We emphasize that our model of an allochthonous tectonic blueschist unit within the Yuli Belt is in agreement with published P-T-data and our structural cross sections, but is, as yet, not corroborated by any more detailed outcrop-scale structural observations along the contacts between the blueschist-facies and metasedimentary unit. Future research should hence focus on investigating kinematics and fault-related fabrics along these contacts. This will allow to test (or falsify) our model further.

\subsection{Palaeogeographic Origin of the Yuli Belt and a Kinematic Evolutionary Scheme}

We consider the dominantly mafic to ultramafic and subordinately metasedimentary blueschist-facies tectonic blocks of the Yuli Belt to have been derived from the oceanic crust of the South China Sea. This interpretation is based on a number of arguments outlined in the following. We minted our arguments into a new kinematic evolutionary three-stage scheme for the Yuli Belt (Fig. 11) and into a palaeogeographic sketch of the South China Sea and the Philippine Sea for $15 \mathrm{Ma}$ (Fig. 12).

(1) Available protolith ages for the blueschists, constrained from U-Pb LA-ICP-MS dating of zircons, are around 15.4 - 16.0 Ma (Chen et al. 2017; Lo et al. 2020), mak- ing them well comparable in age with gabbros from the easterly adjacent, unmetamorphosed ETO accreted to the base of the Lichi Mélange (Hsieh et al. 2017; Huang et al. 2018; Lin et al. 2019; Table 1 and Fig. 2). These ages are about the youngest possible for oceanic crust issued at a mid-oceanic ridge of the South China Sea (Table 1), which ceased spreading at about $15.5 \mathrm{Ma}$ (see section 2 and Fig. 2). The geochemical composition of basalts and gabbros in the ETO has affinities towards a mid-ocean ridge or back-arc basin setting (Lin et al. 2019), although the debate about the origin of the Lichi Mélange is ongoing (e.g., Chang et al. 2000; Huang et al. 2018). Based on these geochemical data and ages, some of the metamorphic rocks in the Yuli Belt probably have affinities with the ETO at the base of the Lichi Mélange. Therefore, we conjecture that the most probable locus, where both the Yuli Belt blueschists and the ETO originated, was to either side of a spreading ridge of the South China Sea (Fig. 11a). We took this idea further by positioning the original locus of these units onto a simple palaeogeographic reconstruction for 15 Ma (Fig. 12). Assuming that both the present-day plate convergence rate of $7-8 \mathrm{~cm} \mathrm{a}^{-1}$ (Seno 1977; Yu et al. 1997) and the NW-SE-oriented convergence direction between Eurasian and Philippine Sea plates (after Seno 1977) were constant during the last $15 \mathrm{Ma}$, we
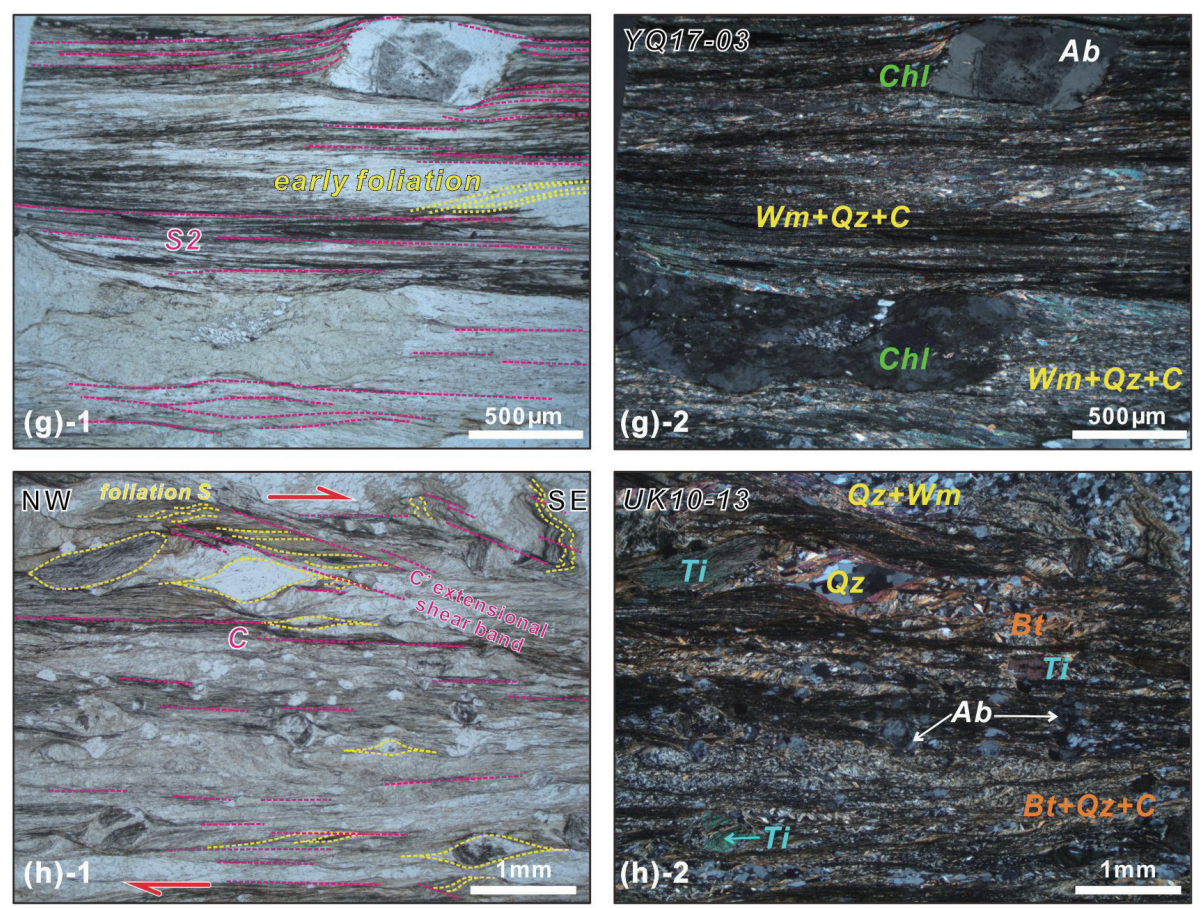

Fig. 9. Microscopic features of albite spotted mica schists from the Hunyeh Hsi and Xinwuliu Hsi areas of the Yuli Belt, respectively. (g)-1 and (h)-1 are in plane-polarized light; (g)-2 and (h)-2 in cross-polarized light. (g): albite-chlorite-mica schists in the Hunyeh Hsi area of Fig. 7d with pressure solution cleavage affecting an asymmetric albite $\sigma$-porphyroclast in metapelites. (h): albite-quartz-mica schists from the Xinwuliu Hsi area of Fig. 7g, showing mylonitic foliations with top-to-SE sense of shear during D3. Abbreviations: $\mathrm{Ab}=$ albite; $\mathrm{C}=$ carbonaceous material; $\mathrm{Chl}=\mathrm{chlo}-$ rite; $\mathrm{Bt}=$ biotite; $\mathrm{Qz}=$ quartz; $\mathrm{Ti}=$ titanite; $\mathrm{Wm}=$ white mica. 

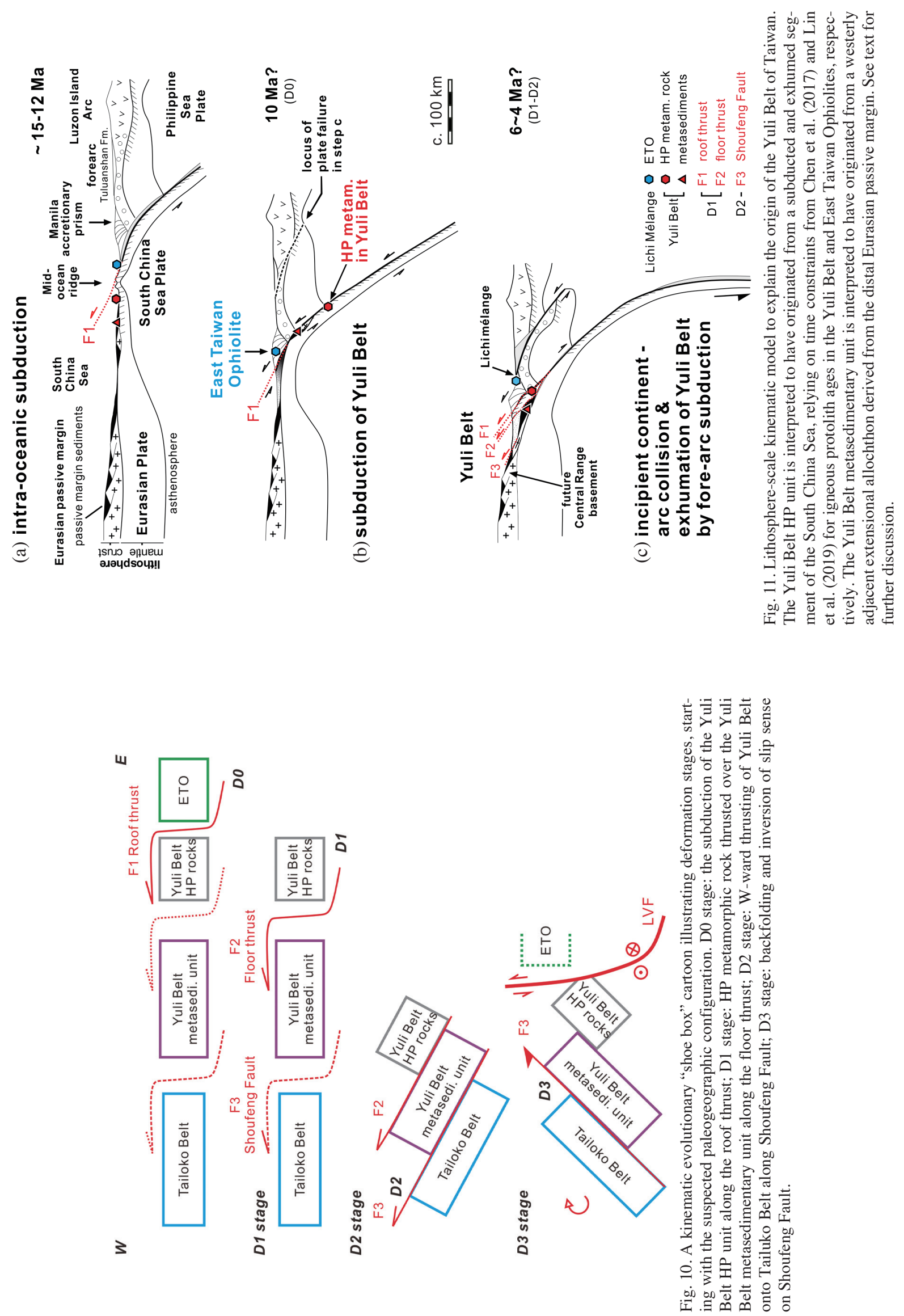


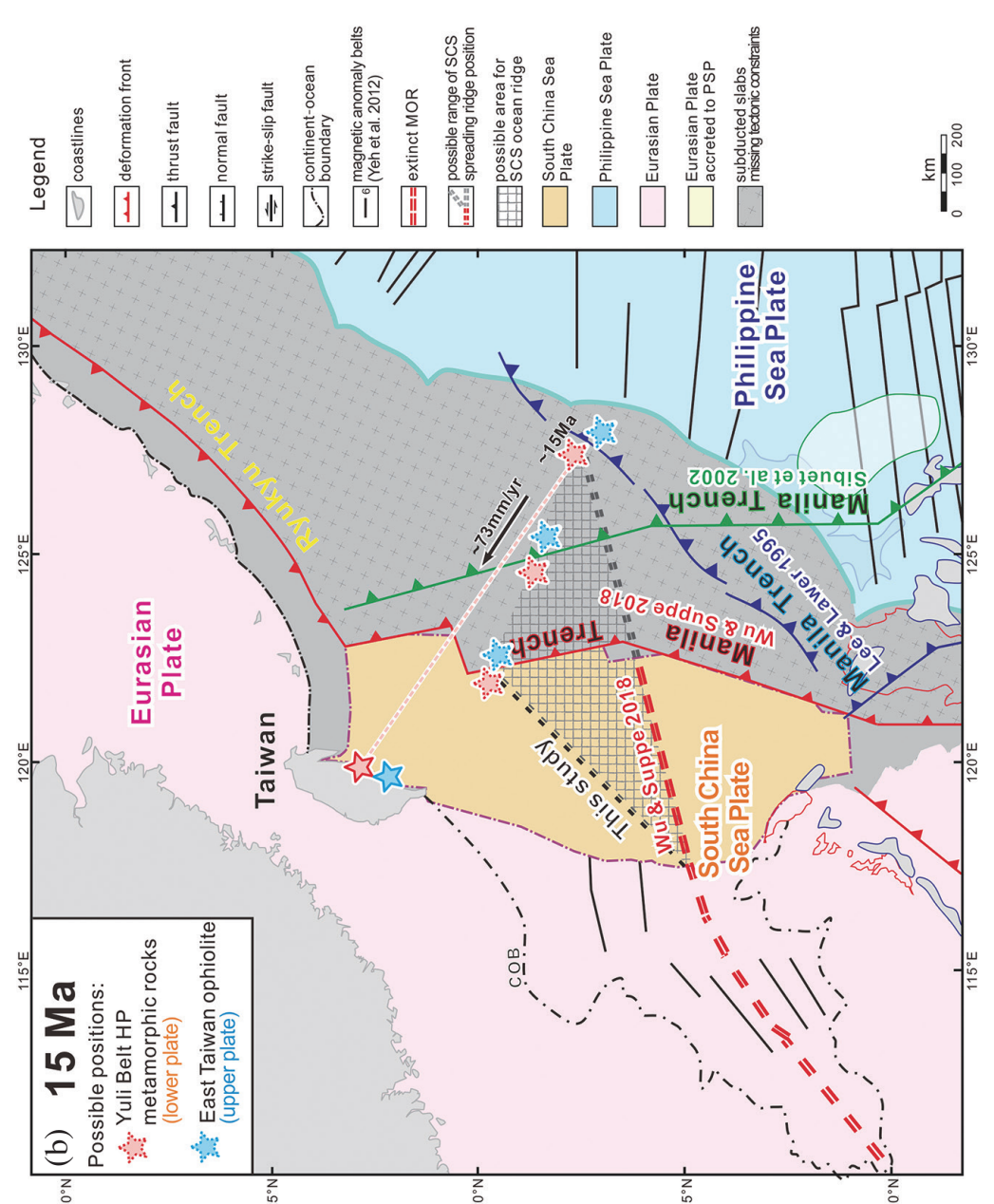

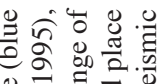
든 管

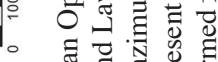

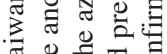

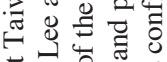

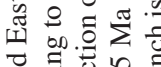
สิ

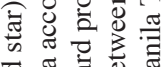

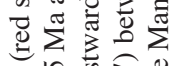
능 至 봉

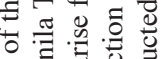

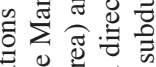

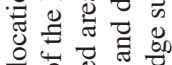
을 记 on 200

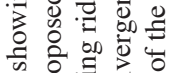

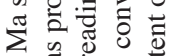
约 후월

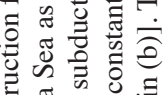

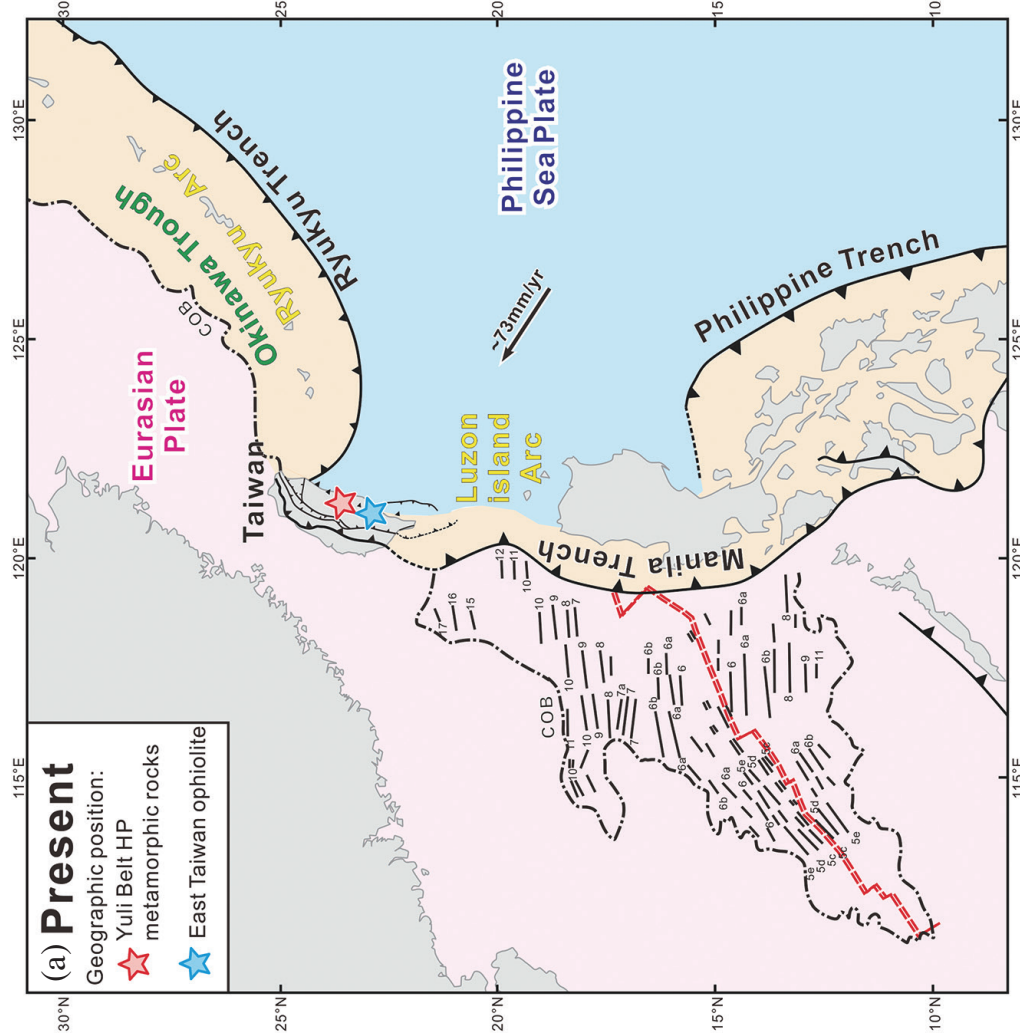

. 굴

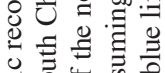

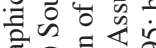

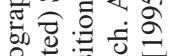
品 $\circ$

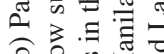
อㄹ.

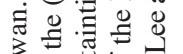

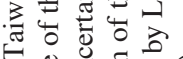

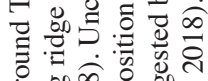

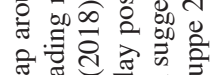
洁 की

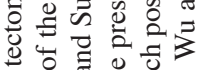

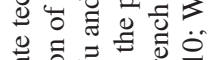

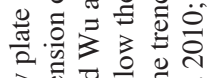

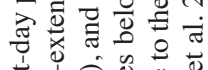

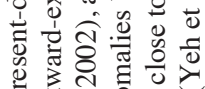

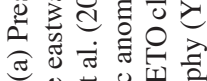
¿

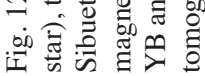


roughly aligned the possible original palaeogeographic locations of both Yuli Belt and ETO on three positions along this trajectory (red and blue dashed stars in Fig. 12b). Given large uncertainties on the trend of the subducted parts of the spreading ridges (cross-hatched area in Fig. 12b), all three pairs of stars mark positions, where South China Sea oceanic crust might have formed near a mid-oceanic ridge at c. 15 Ma. However, only the southeasternmost pair of red and blue dashed stars is in good agreement also with the amount of plate convergence that has occurred since $15 \mathrm{Ma}$, amounting to roughly $1100 \mathrm{~km}$ using the simple assumptions above. This "preferred" position is conspicuously close to the position of the Manila trench reconstructed by Lee and Lawver (1995; blue line in Fig. 12b), which we hence prefer over the two alternative reconstructions of Sibuet et al. (2002; green line in Fig. 12b) and Wu and Suppe (2018; red line in Fig. 12b). These latter reconstructions would only be viable if substantially slower convergence rates operated (Wu and Suppe 2018).

In our kinematic evolutionary sketch (Fig. 11a), we show an intraoceanic subduction zone already operating at $15 \mathrm{Ma}$. This takes account of (i) the oldest reported ages for subduction-related magmatism in the Coastal Range dating back to the Late Oligocene (Table 1 and Fig. 3), (ii) maximum stratigraphic age constraints of the Tuluanshan Fm. in the Coastal Range (Fig. 4) as well as (iii) plate tectonic reconstructions for $15 \mathrm{Ma}$ as discussed above, which show the Manila Trench at variable longitudes in the western Philippine Sea (Lee and Lawver 1995; Sibuet et al. 2002; Wu and Suppe 2018; Fig. 12b).

(2) Subduction of the oceanic crust and lithosphere forming the Yuli Belt blueschists must have commenced soon after $\sim 15 \mathrm{Ma}$ (e.g., Jahn et al. 1981; Lo and Yui 1996), with peak metamorphic conditions reached between 15 and $10 \mathrm{Ma}$ (Chen et al. 2017). At the same time, the ETO has escaped the fate of being subducted, implying that it must have been frontally accreted to the wedge forming along the Manila trench (Fig. 11b). We suspect that the metasedimentary unit of the Yuli Belt, with depositional ages inferred to be as young as mid-Miocene (Chen et al. 2017; Figs. 3 and 4), could have originated as an extensional allochthon derived from the Eurasian distal passive margin, which occupied a paleogeographic position between the proper passive margin and the blueschist unit prior to its subduction (Fig. 11a). Despite the absence of any geochronological data on metamorphic conditions from this unit, we further suspect that it must have closely followed the blueschist unit into subduction (Figs. 11b, S1).

(3) Exhumation of the Yuli Belt series was facilitated by the failure of the upper plate along a lithosphere-scale fault forming between the dense, negatively buoyant fore-arc lithosphere and the more buoyant magmatic Luzon arc upon the entrance of Eurasian continental lithosphere in the trench since ca. 6 - 7 Ma (Chemenda et al. 2001). Subsequently, ongoing convergence led to subduction of the negatively buoyant fore-arc lithosphere by slab extraction (Froitzheim et al. 2003; Shyu et al. 2011; Sandmann et al. 2015; Fig. 11c), a mechanism that very efficiently reduced the overburden on top of the subducted material. We conjecture (i) that this mechanism of slab extraction was at play both for the blueschist-facies units as well as for the metasedimentary unit of the Yuli Belt and (ii) that the juxtaposition of these units along the floor thrust occurred during this stage (Fig. 10). Roof and floor thrust faults of the blueschist-facies unit define part of the suture zone between Eurasian and Philippine Sea Plates, and they likely formed during this stage of fore-arc subduction. We suggest that the easterly adjacent ETO (which is accreted to the base of the Lichi Mélange and from which the Yuli Belt is presently separated by the LVF), should be considered to constitute the remainder of Taiwan's suture zone. Such an assembly with blueschist-facies oceanic units overlain by unmetamorphosed oceanic units is also described from the Chenaillet Ophiolite in the French-Italian Western Alps, where it is attributed to represent the suture between European and Adriatic units (e.g., Manatschal et al. 2011). Furthermore, we suspect that the juxtaposition of the Yuli Belt series and Tailuko belt along the Shoufeng Fault could have occurred within this timespan.

Finally, we realize that it is increasingly difficult to reconcile the Lu-Hf isochron ages of $5.1 \pm 1.7 \mathrm{Ma}$, considered to reflect peak-pressure conditions during blueschistfacies metamorphism (Sandmann et al. 2015) with the fact that between about 6 - 4 Ma continental lithosphere of Eurasia has entered the subduction, dating the transition from intra-oceanic subduction to continent-arc collision (Chi et al. 1981; Suppe 1984; Fig. 11c). The even younger U-Pb ages on zircon rims from nephrite at Fengtien $(3.3 \pm 1.7 \mathrm{Ma}$; Yui et al. 2014), however, may still be geologically viable, as this method possibly dates peak-temperature conditions rather than peak-pressures. In this case, Yui et al. (2014) would have likely obtained an age at which post-collisional shortening during deformation phase D3 was at work. We conclude that further geochronological and structural work is hence needed to better constrain the timing of peak-metamorphic conditions and their structural imprint on the Taiwan orogen.

\section{CONCLUSIONS}

Three new cross-sections across Taiwan's Yuli Belt were constructed, taking new outcrop- to microscope-scale structural observations from several river-transects into account. Our observations suggest that the Yuli Belt was affected by at least three successive deformation phases (D1 to 
D3). We suspect that high-pressure metamorphic units were emplaced on top of metasedimentary units of Yuli Belt along a thrust during D1. This assembly was later thrust over Eurasian-derived series of the Tailuko Belt along the Shoufeng Fault during D2, suggested by (rarely preserved) downplunging stretching lineations on W- to NW-dipping foliation planes. E-vergent open to tight folds throughout the Yuli Belt with $\mathrm{W}$ - to NW-dipping axial planes were produced by the D3 phase, refolding earlier foliations as well as the D1 nappe contact, during which also the blueschist-facies and metasedimentary units were folded. This phase might be related to top-E back-thrusting and a reorientation of the Shoufeng Fault from an initially E-dipping to a presently Wdipping contact. We interpret the high-pressure metamorphic units to form erosional relics of nappe outliers of a formerly more contiguous thrust nappe that hosts part of the suture zone in Taiwan. We suggest that the blueschist-facies metamorphic unit most likely represents a mid-Miocene fragment of oceanic crust and mantle issued in the South China Sea before having been subducted, exhumed and 'sandwiched' between the Tailuko Belt and the easterly adjacent Coastal Ranges derived from the Philippine Sea plate.

Acknowledgements This study was supported by the Deutsche Forschungsgemeinschaft (DFG) project number 380155214 (granted to K.U. and N.F.). K.U. also appreciates financial support through project NSC 97-2811-M002-082 of the National Science Council of Taiwan. C.H.T. acknowledges the research grant (MOST 108-2923-M-259003-MY3) from the Ministry of Science and Technology of Taiwan. We thank Chiao Liu, Wen-Han Lo, Chih-Ying Yeh, Dominikus Deka Dewangga, and Yu-Wei Chang from National Dong Hwa University for fieldwork assistance. We are also grateful to Wei Lo, En-Chao Yeh, Gong-Ruei Ho, and Yu-Huan Hsieh for support in our fieldwork. We extend our thanks to two anonymous reviewers for their very detailed and constructive suggestions that have helped to improve our work, as well as to the editor Prof. R.-J. Rau for his patient and objective treatment of our contribution.

\section{REFERENCES}

Amante, C. and B. W. Eakins, 2009: ETOPO1 1 arc-minute global relief model: Procedures, data sources and analysis. NOAA Technical Memorandum NESDIS NGDC24, National Geophysical Data Center, Marine Geology and Geophysics Division, Boulder, Colorado, 25 pp.

Angelier, J., 1986: Geodynamics of the Eurasia-Philippine Sea Plate Boundary: Preface. Tectonophysics, 125, IXX, doi: 10.1016/0040-1951(86)90003-X. [Link]

Barrier, E. and C. Muller, 1984: New observations and discussion on the origin and age of the Lichi Mélange. Mem. Geol. Soc. China, 6, 303-325.

Baziotis, I., C.-H. Tsai, W. G. Ernst, B.-M. Jahn, and Y.
Iizuka, 2017: New $P-T$ constraints on the Tamayen glaucophane-bearing rocks, eastern Taiwan: Perple_X modelling results and geodynamic implications. $J$. Metamorph. Geol., 35, 35-54, doi: 10.1111/jmg.12218. [Link]

Beyssac, O., F. Negro, M. Simoes, Y. C. Chan, and Y. G. Chen, 2008: High-pressure metamorphism in Taiwan: From oceanic subduction to arc-continent collision? Terr. Nova, 20, 118-125, doi: 10.1111/j.13653121.2008.00796.x. [Link]

Briais, A., P. Patriat, and P. Tapponnier, 1993: Updated interpretation of magnetic anomalies and seafloor spreading stages in the south China Sea: Implications for the Tertiary tectonics of Southeast Asia. J. Geophys. Res., 98, 6299-6328, doi: 10.1029/92JB02280. [Link]

Brown, D., J. Alvarez-Marron, M. Schimmel, Y.-M. Wu, and G. Camanni, 2012: The structure and kinematics of the central Taiwan mountain belt derived from geological and seismicity data. Tectonics, 31, doi: 10.1029/2012tc003156. [Link]

Chang, C.-P., J. Angelier, and C.-Y. Huang, 2000: Origin and evolution of a mélange: The active plate boundary and suture zone of the Longitudinal Valley, Taiwan. Tectonophysics, 325, 43-62, doi: 10.1016/S00401951(00)00130-X. [Link]

Chang, S. S. L. and W.-R. Chi, 1983: Neogene Nannoplankton biostratigraphy in Taiwan and the tectonic implications. Petrol. Geol. Taiwan, 19, 93-147.

Chemenda, A. I., R.-K. Yang, J.-F. Stephan, E. A. Konstantinovskaya, and G. M. Ivanov, 2001: New results from physical modelling of arc-continent collision in Taiwan: Evolutionary model. Tectonophysics, 333, 159178, doi: 10.1016/s0040-1951(00)00273-0. [Link]

Chen, C.-H. and C.-H. Wang, 1995: Explanatory notes for the metamorphic facies map of Taiwan. Special publication of the Central Geological Survey, No. 2, 2nd Edition, $51 \mathrm{pp}$.

Chen, C.-H., T. F. Yang, J. Tien, and T. Lee, 1992: Eruption ages of north Luzon Arc (Taiwan): Based on fissiontrack dating. Acta Geol. Taiwan., 30, 149-156.

Chen, W.-H., C.-Y. Huang, Y.-J. Lin, Q. Zhao, Y. Yan, D. Chen, X. Zhang, Q. Lan, and M. Yu, 2015: Depleted deep South China Sea $\delta^{13} \mathrm{C}$ paleoceanographic events in response to tectonic evolution in Taiwan-Luzon Strait since Middle Miocene. Deep-Sea Res. Part IITop. Stud. Oceanogr., 122, 195-225, doi: 10.1016/j. dsr2.2015.02.005. [Link]

Chen, W.-S., K. D. Ridgway, C.-S. Horng, Y.-G. Chen, K.S. Shea, and M.-G. Yeh, 2001: Stratigraphic architecture, magnetostratigraphy, and incised-valley systems of the Pliocene-Pleistocene collisional marine foreland basin of Taiwan. Geol. Soc. Am. Bull., 113, 1249-1271, doi: 10.1130/0016-7606(2001)113<1249:SAMAIV>2 .0.CO;2. [Link] 
Chen, W.-S., S.-L. Chung, H.-Y. Chou, Z. Zugeerbai, W.Y. Shao, and Y.-H. Lee, 2017: A reinterpretation of the metamorphic Yuli belt: Evidence for a middle-late Miocene accretionary prism in eastern Taiwan. Tectonics, 36, 188-206, doi: 10.1002/2016TC004383. [Link]

Chen, W.-S., J.-J. Yeh, and S.-J. Syu, 2019: Late Cenozoic exhumation and erosion of the Taiwan orogenic belt: New insights from petrographic analysis of foreland basin sediments and thermochronological dating on the metamorphic orogenic wedge. Tectonophysics, $\mathbf{7 5 0}$, 56-69, doi: 10.1016/j.tecto.2018.09.003. [Link]

Chi, W.-R., J. Namson, and J. Suppe, 1981: Stratigraphic record of plate interactions in the Coastal Range of Eastern Taiwan. Mem. Geol. Soc. China, 4, 155-194.

Chiang, S.-F., 2003: Original and metamorphic P-T evolution of porphyroblastic albites of spotted schists in Juisui, Hualien. Master Thesis, National Central University, Taiwan, $120 \mathrm{pp}$.

Clark, M. B., D. M. Fisher, and C.-Y. Lu, 1992: Strain variations in the Eocene and older rocks exposed along the Central and Southern cross-island highways, Taiwan. Science Reports of the National Taiwan University ACTA Oceanographica Taiwanica, 30, 1-10.

Conand, C., F. Mouthereau, J. Ganne, A. T.-S. Lin, A. Lahfid, M. Daudet, L. Mesalles, S. Giletycz, and M. Bonzani, 2020: Strain partitioning and exhumation in oblique Taiwan collision: Role of rift architecture and plate kinematics. Tectonics, 39, e2019TC005798, doi: 10.1029/2019tc005798. [Link]

Condie, K. C., 2016: Earth as an Evolving Planetary System, 3rd Edition, Academic Press, 430 pp, doi: 10.1016/ C2015-0-00179-4. [Link]

Crespi, J. M., Y.-C. Chan, and M. S. Swaim, 1996: Synorogenic extension and exhumation of the Taiwan hinterland. Geology, 24, 247-250, doi: 10.1130/0091-7613(1996)024<0247:SEAEOT>2.3 . CO;2. [Link]

Dewey, J. F., 1987: Suture. In: Seyfert, C. (Ed.), Structural Geology and Tectonics, Encyclopedia of Earth Science, Springer, Berlin, Heidelberg, 775-784, doi: 10.1007/3-540-31080-0_115. [Link]

Dorsey, R. J., 1992: Collapse of the Luzon Volcanic Arc during onset of arc-continent collision: Evidence from a Miocene-Pliocene unconformity, eastern Taiwan. Tectonics, 11, 177-191, doi: 10.1029/91tc02463. [Link]

Ernst, W. G. and B. M. Jahn, 1987: Crustal accretion and metamorphism in Taiwan, a post-Palaeozoic mobile belt. Philos. Trans. R. Soc. Lond. Ser. A-Math. Phys. Eng. Sci., 321, 129-161, doi: 10.1098/rsta.1987.0008. [Link]

Faure, M., C.-Y. Lu, and H.-T. Chu, 1991: Ductile deformation and Miocene nappe-stacking in Taiwan related to motion of the Philippine Sea Plate. Tectonophysics,
198, 95-105, doi: 10.1016/0040-1951(91)90134-E. [Link]

Fisher, D. M., 1999: Orogen-parallel extension in the Eastern Central range of Taiwan. J. Geol. Soc. China, 42, 41-58.

Fisher, D. M., C.-Y. Lu, and H.-T. Chu, 2002: Taiwan slate belt: Insights into the ductile interior of an arc-continent collision. In: Byrne, T. B. and C.-S. Liu (Eds.), Geology and Geophysics of an Arc-Continent Collision, Taiwan, Vol. 358, Geological Society of America, 93-106, doi: 10.1130/0-8137-2358-2.93. [Link]

Fisher, D. M., S. Willett, E.-C. Yeh, and M. B. Clark, 2007: Cleavage fronts and fans as reflections of orogen stress and kinematics in Taiwan. Geology, 35, 65-68, doi: 10.1130/G22850A.1. [Link]

Froitzheim, N., J. Pleuger, S. Roller, and T. Nagel, 2003: Exhumation of high- and ultrahigh-pressure metamorphic rocks by slab extraction. Geology, 31, 925-928, doi: 10.1130/G19748.1. [Link]

Gansser, A., 1964: Geology of the Himalayas, Wiley-Interscience, New York, 289 pp.

Gansser, A., 1980: The significance of the Himalayan suture zone. Tectonophysics, 62, 37-52, doi: 10.1016/00401951(80)90134-1. [Link]

Gradstein, F. M., J. G. Ogg, M. D. Schmitz, and G. M. Ogg, 2012: The Geologic Time Scale, Elsevier, 1176 pp, doi: 10.1016/C2011-1-08249-8. [Link]

Grasemann, B. and B. Huet, 2016: Orogeny. In: Harff, J., M. Meschede, S. Petersen, and J. Thiede (Eds.), Encyclopedia of Marine Geosciences, Encyclopedia of Earth Sciences Series, Springer, Dordrecht, 602-610, doi: 10.1007/978-94-007-6238-1_123. [Link]

Ho, C. S., 1986: A synthesis of the geologic evolution of Taiwan. Tectonophysics, 125, 1-16, doi: 10.1016/00401951(86)90004-1. [Link]

Ho, G.-R., 2015: The structural evolution of the Tananao Complex, Taiwan - Taking examples from Hopin, Wanrung and Southern cross-island highway. Ph.D. Thesis, National Taipei University of Technology, 95 pp. (in Chinese with English abstract)

Ho, G.-R. and W. Lo, 2015: Structural analysis in Shoufengsi area of Tananao Complex, eastern Taiwan. Terr. Atmos. Ocean. Sci., 26, 557-569, doi: 10.3319/ TAO.2015.05.15.01(TT). [Link]

Hsieh, R. B.-J., J. G. Shellnutt, and M.-W. Yeh, 2017: Age and tectonic setting of the East Taiwan Ophiolite: Implications for the growth and development of the South China Sea. Geol. Mag., 154, 441-455, doi: 10.1017/ S0016756816000054. [Link]

Hsu, S.-K., Y. Yeh, W.-B. Doo, and C.-H. Tsai, 2004: New Bathymetry and Magnetic Lineations Identifications in the Northernmost South China Sea and their Tectonic Implications. Mar. Geophys. Res., 25, 29-44, doi: 10.1007/s1 1001-005-0731-7. [Link] 
Hu, H.-N. and S. F. Tsan, 1984: Structural study of the Slate Formation along the South Link Railroad, Taiwan. Spec. Publ. Central Geol. Surv., 3, 25-43. (in Chinese)

Huang, C.-Y., P. B. Yuan, and S.-J. Tsao, 2006: Temporal and spatial records of active arc-continent collision in Taiwan: A synthesis. Geol. Soc. Am. Bull., 118, 274288, doi: 10.1130/b25527.1. [Link]

Huang, C.-Y., W.-H. Chen, M.-H. Wang, C.-T. Lin, S. Yang, X. Li, M. Yu, X. Zhao, K.-M. Yang, C.-S. Liu, Y.-H. Hsieh, and R. Harris, 2018: Juxtaposed sequence stratigraphy, temporal-spatial variations of sedimentation and development of modern-forming forearc Lichi Mélange in North Luzon Trough forearc basin onshore and offshore eastern Taiwan: An overview. Earth-Sci. Rev., 182, 102-140, doi: 10.1016/j.earscirev.2018.01.015. [Link]

Huang, T.-C., J.-S. Ting, and C. Muller, 1983: A note on Pliocene microfossils from the Kenting mélange. Proc. Geol. Soc. China, 26, 57-66.

Jahn, B.-M. and J.-G. Liou, 1977: Age and geochemical constraints of glaucophane schists of Taiwan. Mem. Geol. Soc. China, 2, 129-140.

Jahn, B.-M., J.-G. Liou, and H. Nagasawa, 1981: High-pressure Metamorphic Rocks of Taiwan: REE Geochemistry, $\mathrm{Rb}-\mathrm{Sr}$ Ages and Tectonic Implications. Mem. Geol. Soc. China, 4, 497-520.

Jahn, B. M., F. Martineau, J. J. Peucat, and J. Cornichet, 1986: Geochronology of the Tananao Schist complex, Taiwan, and its regional tectonic significance. Tectonophysics, 125, 103-124, doi: 10.1016/00401951(86)90009-0. [Link]

Juang, W.-S., 1988: Geochronology and chemical variations of late Cenozoic volcanic rocks in Taiwan. Ph.D. Thesis, National Taiwan University, Taipei, 231 pp.

Juang, W.-S. and H. Bellon, 1986: Potassium-Argon Ages of the Tananao Schist in Taiwan. Mem. Geol.Soc. Chi$n a, 7,405-416$.

Juang, W.-S. and J.-C. Chen, 1990: Geochronology and chemical variations of volcanic rocks along the arccontinent collision zone in eastern Taiwan. Bulletin of the National Museum of Natural Science, 2, 89-118.

Kao, H., G.-C. Huang, and C.-S. Liu, 2000: Transition from oblique subduction to collision in the northern Luzon arc-Taiwan region: Constraints from bathymetry and seismic observations. J. Geophys. Res., 105, 30593079, doi: 10.1029/1999JB900357. [Link]

Keyser, W., C.-H. Tsai, Y. Iizuka, R. Oberhänsli, and W. G. Ernst, 2016: High-pressure metamorphism in the Chinshuichi area, Yuli belt, eastern Taiwan. Tectonophysics, 692, 191-202, doi: 10.1016/j.tecto.2015.09.012. [Link]

Lan, C.-Y. and J.-G. Liou, 1981: Occurrence, petrology and tectonics of serpentinites and associated rodingites in the Central Range, Taiwan. Mem. Geol. Soc. China,

\section{4, 343-389.}

Lan, C.-Y. and J.-G. Liou, 1984: Mineral chemistry of metamorphosed oceanic rocks in the Yuli Belt of the Tananao schist, Taiwan. Mem. Geol. Soc. China, 6, 153-178.

Lan, C.-Y., B.-M. Jahn, S. A. Mertzman, and T.-W. Wu, 1996: Subduction-related granitic rocks of Taiwan. $J$. Southeast Asian Earth Sci., 14, 11-28, doi: 10.1016/ S0743-9547(96)00017-7. [Link]

Lee, T.-Y. and L. A. Lawver, 1995: Cenozoic plate reconstruction of Southeast Asia. Tectonophysics, 251, 85138, doi: 10.1016/0040-1951(95)00023-2. [Link]

Lee, Y.-H., T. Byrne, W.-H. Wang, W. Lo, R.-J. Rau, and H.-Y. Lu, 2015: Simultaneous mountain building in the Taiwan orogenic belt. Geology, 43, 451-454, doi: 10.1130/G36373.1. [Link]

Li, Q., G. Wu, L. Zhang, Y. Shu, and L. Shao, 2017: Paleogene marine deposition records of rifting and breakup of the South China Sea: An overview. Sci. China Earth Sci., 60, 2128-2140, doi: 10.1007/s11430-016-0163-x. [Link]

Lin, A. T. and A. B. Watts, 2002: Origin of the West Taiwan basin by orogenic loading and flexure of a rifted continental margin. J. Geophys. Res., 107, ETG 2-1-ETG 2-19, doi: 10.1029/2001JB000669. [Link]

Lin, A. T., A. B. Watts, and S. P. Hesselbo, 2003: Cenozoic stratigraphy and subsidence history of the South China Sea margin in the Taiwan region. Basin Res., 15, 453478, doi: 10.1046/j.1365-2117.2003.00215.x. [Link]

Lin, C.-T., R. Harris, W.-D. Sun, and G.-L. Zhang, 2019: Geochemical and geochronological constraints on the origin and emplacement of the East Taiwan Ophiolite. Geochem. Geophys. Geosyst., 20, 2110-2133, doi: 10.1029/2018GC007902. [Link]

Lin, C.-W. and W.-S. Chen, 2016: Geologic Map of Taiwan, Geological Society of Taiwan, Taiwan.

Lin, M.-L., C.-N. Yang, and Y. Wang, 1984: Petrotectonic study on the Yuli belt of the Tananao Schist in the Chinshuichi area, eastern Taiwan. Science Reports of the National Taiwan University ACTA Geologica Taiwanica, 22, 151-188.

Liou, J.-G., 1981: Petrology of metamorphosed oceanic rocks in the Central Range of Taiwan. Mem. Geol.Soc. China, 4, 291-341.

Liou, J.-G. and W. G. Ernst, 1984: Summary of Phanerozoic metamorphism in Taiwan. Mem. Geol. Soc. China, $\mathbf{6}$, 133-152.

Liou, J. G., C. O. Ho, and T. P. Yen, 1975: Petrology of some Glaucophane Schists and Related Rocks from Taiwan. J. Petrol., 16, 80-109, doi: 10.1093/petrology/16.1.80. [Link]

Lo, C.-H. and T.-F. Yui, 1996: ${ }^{40} \mathrm{Ar} /{ }^{39} \mathrm{Ar}$ dating of highpressure rocks in the Tananao basement complex, Taiwan. J. Geol. Soc. China, 39, 13-30. 
Lo, C.-H., T. C. Onstott, C.-H. Chen, and T. Lee, 1994: An assessment of ${ }^{40} \mathrm{Ar} /{ }^{39} \mathrm{Ar}$ dating for the wholerock volcanic samples from the Luzon Arc near Taiwan. Chem. Geol., 114, 157-178, doi: 10.1016/00092541(94)90049-3. [Link]

Lo, W.-H., 2018: Zircon U-Pb geochronological constraints and whole-rock geochemical characteristics of metamorphic rocks in the Chinshuichi area of the Yuli belt, eastern Taiwan. Master Thesis, National Dong Hwa University, Taiwan, $136 \mathrm{pp}$.

Lo, Y.-C., C.-T. Chen, C.-H. Lo, and S.-L. Chung, 2020: Ages of ophiolitic rocks along plate suture in Taiwan orogen: Fate of the South China Sea from subduction to collision. Terr. Atmos. Ocean. Sci., 31, 383-402, doi: 10.3319/TAO.2019.06.19.01. [Link]

Malavieille, J., S. E. Lallemand, S. Dominguez, A. Deschamps, C.-Y. Lu, C.-S. Liu, P. Schnuerle, J. Angelier, J. Y. Collot, B. Deffontaines, M. Fournier, S. K. Hsu, J. P. Le Formal, S. Y. Liu, J. C. Sibuet, N. Thareau, and F. Wang, 2002: Arc-continent collision in Taiwan: New marine observations and tectonic evolution. In: Byrne, T. B. and C.-S. Liu (Eds.), Geology and Geophysics of an Arc-Continent Collision, Taiwan, Vol. 358, Geological Society of America, 187-211, doi: 10.1130/0-8137-2358-2.187. [Link]

Manatschal, G., D. Sauter, A. M. Karpoff, E. Masini, G. Mohn, and Y. Lagabrielle, 2011: The Chenaillet Ophiolite in the French/Italian Alps: An ancient analogue for an Oceanic Core Complex? Lithos, 124, 169-184, doi: 10.1016/j.lithos.2010.10.017. [Link]

Maruyama, S., M. Cho, and J. G. Liou, 1986: Experimental investigations of blueschist-greenschist transition equilibria: Pressure dependence of $\mathrm{Al}_{2} \mathrm{O}_{3}$ contents in sodic amphiboles-A new geobarometer. In: Evans, B. W. and E. H. Brown (Eds.), Blueschists and Eclogites, Vol. 164, Geological Society of America, 1-16, doi: 10.1130/MEM164-p1. [Link]

Mondro, C. A., D. Fisher, and E.-C. Yeh, 2017: Strain histories from the eastern Central Range of Taiwan: A record of advection through a collisional orogen. Tectonophysics, 705,1-11, doi: 10.1016/j.tecto.2017.03.007. [Link]

Moores, E., 1970: Ultramafics and Orogeny, with Models of the US Cordillera and the Tethys. Nature, 228, 837842, doi: 10.1038/228837a0. [Link]

Moores, E. M. and F. J. Vine, 1971: The Troodos Massif, Cyprus and other ophiolites as oceanic crust: Evaluation and implications. Philos. Trans. R. Soc. Lond. Ser. A-Math. Phys. Eng. Sci., 268, 443-467, doi: 10.1098/ rsta.1971.0006. [Link]

Naylor, M. and H. D. Sinclair, 2007: Punctuated thrust deformation in the context of doubly vergent thrust wedges: Implications for the localization of uplift and exhumation. Geology, 35, 559-562, doi: 10.1130/
G23448A.1. [Link]

Ota, T. and Y. Kaneko, 2010: Blueschists, eclogites, and subduction zone tectonics: Insights from a review of Late Miocene blueschists and eclogites, and related young high-pressure metamorphic rocks. Gondwana Res., 18, 167-188, doi: 10.1016/j.gr.2010.02.013. [Link]

Page, B. M. and C. Y. Lan, 1983: The Kenting mélange and its record of tectonic events. Mem. Geol. Soc. China, 5, 227-248.

Pelletier, B. and H.-N. Hu, 1984: New structural data along two transects across the southern half of the Central Range of Taiwan. Mem. Geol. Soc. China, 6, 1-19.

Pelletier, B. and J. F. Stephan, 1986: Middle miocene deduction and late miocene beginning of collision registered in the hengchun peninsula: Geodynamic implications for the evolution of Taiwan. Tectonophysics, 125, 133-160, doi: 10.1016/0040-1951(86)90011-9. [Link]

Reed, D. L., N. Lundberg, C.-S. Liu, and B.-Y. Kuo, 1992: Structural relations along the margins of the offshore Taiwan accretionary wedge: Implications for accretion and crustal kinematics. Science Reports of the National Taiwan University ACTA Geologica Taiwanica, 30, 105-122.

Richard, M., H. Bellon, R. C. Maury, E. Barrier, and W.S. Juang, 1986: Miocene to recent calc-alkalic volcanism in eastern Taiwan: K-Ar ages and petrography. Tectonophysics, 125, 87-102, doi: 10.1016/00401951(86)90008-9. [Link]

Sandmann, S., T. J. Nagel, N. Froitzheim, K. Ustaszewski, and C. Münker, 2015: Late Miocene to early Pliocene blueschist from Taiwan and its exhumation via forearc extraction. Terr. Nova, 27, 285-291, doi: 10.1111/ ter.12158. [Link]

Seno, T., 1977: The instantaneous rotation vector of the Philippine Sea plate relative to the Eurasian plate. Tectonophysics, 42, 209-226, doi: 10.1016/00401951(77)90168-8. [Link]

Shao, W.-Y., S.-L. Chung, W.-S. Chen, H.-Y. Lee, and L.W. Xie, 2015: Old continental zircons from a young oceanic arc, eastern Taiwan: Implications for Luzon subduction initiation and Asian accretionary orogeny. Geology, 43, 479-482, doi: 10.1130/g36499.1. [Link]

Shen, C.-C. and H.-Y. Yang, 1996: A study on the paragonite in the metamorphic terrane of Taiwan. Bulletin of the Central Geological Survey, 11, 85-104. (in Chinese with English abstract)

Shen, P., H.-T. Chu, and R.-C. Jeng, 1984: Electron microscopy observations of the plagiogranite from east Taiwan ophiolite. Mem. Geol. Soc. China, 6, 211-218.

Shyu, J. B. H., K. Sieh, Y.-G. Chen, and C.-S. Liu, 2005: Neotectonic architecture of Taiwan and its implications for future large earthquakes. J. Geophys. Res., 110, B08402, doi: 10.1029/2004JB003251. [Link] 
Shyu, J. B. H., Y.-M. Wu, C.-H. Chang, and H.-H. Huang, 2011: Tectonic erosion and the removal of forearc lithosphere during arc-continent collision: Evidence from recent earthquake sequences and tomography results in eastern Taiwan. J. Asian Earth Sci., 42, 415-422, doi: 10.1016/j.jseaes.2011.05.015. [Link]

Sibuet, J.-C., S.-K. Hsu, X. Le Pichon, J.-P. Le Formal, D. Reed, G. Moore, and C.-S. Liu, 2002: East Asia plate tectonics since $15 \mathrm{Ma}$ : Constraints from the Taiwan region. Tectonophysics, 344, 103-134, doi: 10.1016/ S0040-1951(01)00202-5. [Link]

Sibuet, J.-C., Y.-C. Yeh, and C.-S. Lee, 2016: Geodynamics of the South China Sea. Tectonophysics, 692, 98-119, doi: 10.1016/j.tecto.2016.02.022. [Link]

Stanley, R. S., L. B. Hill, H. C. Chang, and H.-N. Hu, 1981: A transect through the metamorphic core of the central mountains, southern Taiwan. Mem. Geol. Soc. China, 4, 443-473.

Stern, R. J., 2005: Evidence from ophiolites, blueschists, and ultrahigh-pressure metamorphic terranes that the modern episode of subduction tectonics began in Neoproterozoic time. Geology, 33, 557-560, doi: 10.1130/ G21365.1. [Link]

Suppe, J., 1984: Kinematics of arc-continent collision, flipping of subduction, and back-arc spreading near Taiwan. Mem. Geol. Soc. China, 6, 21-33.

Suppe, J. and J.-G. Liou, 1979: Tectonics of the Lichi Melange and East Taiwan Ophiolite. Mem. Geol. Soc. China, 3, 147-153.

Suppe, J., C.-Y. Lan, E. M. Hendel, and J.-G. Liou, 1977: Paleogeographic interpretation of red shales within the East Taiwan Ophiolite. Petrol. Geol. Taiwan, 14, 109-120.

Taylor, B. and D. E. Hayes, 1983: Origin and history of the South China Sea Basin. In: Hayes, D. E. (Ed.), The Tectonic and Geologic Evolution of Southeast Asian Seas and Islands: Part 2, Volume 27, American Geophysical Union, Washington, DC, 23-56, doi: 10.1029/ gm027p0023. [Link]

Teng, L. S., 1990: Geotectonic evolution of late Cenozoic arc-continent collision in Taiwan. Tectonophysics, 183, 57-76, doi: 10.1016/0040-1951(90)90188-e. [Link]

Tian, Z.-X., Y. Yan, C.-Y. Huang, X.-C. Zhang, H.-Q. Liu, M.-M. Yu, D. Yao, and Y. Dilek, 2019: Geochemistry and geochronology of the accreted mafic rocks from the Hengchun Peninsula, southern Taiwan: Origin and tectonic implications. J. Geophys. Res., 124, 24692491, doi: 10.1029/2018JB016562. [Link]

Tsai, C.-H., Y. Iizuka, and W. G. Ernst, 2013: Diverse mineral compositions, textures, and metamorphic $P-T$ conditions of the glaucophane-bearing rocks in the Tamayen mélange, Yuli belt, eastern Taiwan. J. Asian Earth Sci., 63, 218-233, doi: 10.1016/j.jseaes.2012.09.019. [Link]
Tsao, S., E. Law, H.-C. Ho, Y.-H. Lee, W .-T. Jiang, and C.H. Chen, 1996: The geological significances of K-Ar ages of metapelites from the Central Range, Taiwan. Bulletin of the Central Geological Survey, 11, 37-84.

Wang, Y., C.-N. Yang, and W.-S. Chen, 1992: Yuli, The Geological Map of Taiwan Scale 1:50,000, No. 48, Central Geological Survey, MOEA, Taiwan.

Wang, Y., C.-H. Tsai, L. Zhou, Y. Qiu, and G. Sun, 2017: Reassessment of the Mesozoic metasedimentary rocks and tectonic setting of Taiwan and the adjacent continental margin of eastern Asia. Geol. Mag., 154, 11271154, doi: 10.1017/s0016756816000741. [Link]

Whitney, D. L. and B. W. Evans, 2010: Abbreviations for names of rock-forming minerals. Am. Mineral., 95, 185-187, doi: 10.2138/am.2010.3371. [Link]

Wu, J. and J. Suppe, 2018: Proto-South China Sea Plate Tectonics Using Subducted Slab Constraints from Tomography. J. Earth Sci., 29, 1304-1318, doi: 10.1007/ s12583-017-0813-x. [Link]

Wu, Y.-M., C.-H. Chang, L. Zhao, T.-L. Teng, and M. Nakamura, 2008: A Comprehensive Relocation of Earthquakes in Taiwan from 1991 to 2005. Bull. Seismol. Soc. Am., 98, 1471-1481, doi: 10.1785/0120070166. [Link]

Yang, C.-N. and Y. Wang, 1985: Petrotectonic study on the Yuli belt of the Tananao Schist in the Juisui area, eastern Taiwan. Science Reports of the National Taiwan University ACTA Geologica Taiwanica, 23, 153-180.

Yang, H.-Y. and S.-J. Lin, 1982: The porphyroblastic garnet and the garnet-hornblende-epidote-paragonite schist from Tamayenshan, Juisui, Eastern Taiwan. Proc. Geol. Soc. China, 25, 82-87.

Yang, T. F., J. Tien, C.-H. Chen, T. Lee, and R. S. Punongbayan, 1995: Fission-track dating of volcanics in the northern part of the Taiwan-Luzon Arc: Eruption ages and evidence for crustal contamination. J. Southeast Asian Earth Sci., 11, 81-93, doi: 10.1016/07439547(94)00041-C. [Link]

Yeh, E.-C., 2004: Structural evolution of slate belts: Examples from Taiwan and eastern Pennsylvania. Ph.D. Thesis, The Pennsylvania State University, USA, 207 pp.

Yeh, Y.-C., J.-C. Sibuet, S.-K. Hsu, and C.-S. Liu, 2010: Tectonic evolution of the Northeastern South China Sea from seismic interpretation. J. Geophys. Res., 115, B06103, doi: 10.1029/2009jb006354. [Link]

Yen, T.-P., 1959: The minerals of the Tananao Schist of Taiwan. Bull. Geol. Surv. Taiwan, 11, 1-53.

Yen, T.-P., 1963: The metamorphic belts within the Tananao schist terrain of Taiwan. Proc. Geol. Soc. China, 6, 72-74.

Yen, T.-P., 1966: Glaucophane schist of Taiwan. Proc. Geol. Soc. China, 9, 70-73.

Yi, T., Z.-Y. Chen, and C.-W. Lin, 2012: Guangfu, The 
Geological Map of Taiwan Scale 1:50,000, No. 41, Central Geological Survey, MOEA, Taiwan.

Yu, H.-S. and Y.-W. Chou, 2001: Characteristics and development of the flexural forebulge and basal unconformity of Western Taiwan Foreland Basin. Tectonophysics, 333, 277-291, doi: 10.1016/S0040-1951(00)00279-1. [Link]

Yu, S.-B., H.-Y. Chen, and L.-C. Kuo, 1997: Velocity field of GPS stations in the Taiwan area. Tectonophysics, 274, 41-59, doi: 10.1016/S0040-1951(96)00297-1. [Link]

Yue, L.-F., J. Suppe, and J.-H. Hung, 2005: Structural geology of a classic thrust belt earthquake: The 1999 ChiChi earthquake Taiwan $\left(M_{\mathrm{w}}=7.6\right)$. J. Struct. Geol., 27, 2058-2083, doi: 10.1016/j.jsg.2005.05.020. [Link]
Yui, T.-F. and C.-H. Lo, 1989: High-pressure metamorphosed ophiolitic rocks from the Wanjung area, Taiwan. Proc. Geol. Soc. China, 32, 47-62.

Yui, T.-F., K. Maki, C. Y. Lan, T. Hirata, H. T. Chu, Y. Kon, T. D. Yokoyama, B. M. Jahn, and W. G. Ernst, 2012: Detrital zircons from the Tananao metamorphic complex of Taiwan: Implications for sediment provenance and Mesozoic tectonics. Tectonophysics, 541543, 31-42, doi: 10.1016/j.tecto.2012.03.013. [Link]

Yui, T.-F., T. Usuki, C.-Y. Chen, A. Ishida, Y. Sano, K. Suga, Y. lizuka, and C.-T. Chen, 2014: Dating thin zircon rims by NanoSIMS: The Fengtien nephrite (Taiwan) is the youngest jade on Earth. Int. Geol. Rev., 56, 1932-1944, doi: 10.1080/00206814.2014.972994. [Link] 